\title{
A TECHNICAL DESCRIPTION OF THE NRC LONG-TERM WHOLE ROD AND CRUD PERFORMANCE TEST
}

\author{
DO NOT MICROFILM \\ COVER
}

\section{Hanford Engineering Development Laboratory \\ R.E. Einziger \\ R.L. Fish \\ R.L. Knecht}

Prepared for the U.S. Nuclear Regulatory Commission 


\section{DISCLAIMER}

This report was prepared as an account of work sponsored by an agency of the United States Government. Neither the United States Government nor any agency Thereof, nor any of their employees, makes any warranty, express or implied, or assumes any legal liability or responsibility for the accuracy, completeness, or usefulness of any information, apparatus, product, or process disclosed, or represents that its use would not infringe privately owned rights. Reference herein to any specific commercial product, process, or service by trade name, trademark, manufacturer, or otherwise does not necessarily constitute or imply its endorsement, recommendation, or favoring by the United States Government or any agency thereof. The views and opinions of authors expressed herein do not necessarily state or reflect those of the United States Government or any agency thereof. 


\section{DISCLAIMER}

Portions of this document may be illegible in electronic image products. Images are produced from the best available original document. 


\section{NOTICE}

This report was prepared as an account of work sponsored by an agency of the United States Government. Neither the United States Government nor any agency thereof, or any of their employees, makes any warranty, expressed or implied, or assumes any legal liability of responsibility for any third party's use, or the results of such use, of any information, apparatus, product or process disclosed in this report, or represents that its use by such third party would not infringe privately owned rights.

\section{Availability of Reference Materials Cited in NRC Publications}

Most documents cited in NRC publications will be avallable trom one of the following sources:

1. The NRC Public Document Room, 1717 H Street, N.W. Washington, DC 20555

2. The NRC/GPO Sales Program, U.S. Nuclear Regulatory Commission, Washington, DC 20555

3. The National Technical Information Service, Springfield, VA 22161

Although the listing that follows represents the majority of documents cited in NRC publications, it is not intended to be exhaustive.

Referenced documents available for inspection and copying for a fee from the NRC Public Document Room include NRC correspondence and iriternal NRC memoranda; NRC Office of Inspection and Enforcement bulletins, circulars, information notices, inspection and investigation notices; Licensee Event Reports; vendor reports and correspondence; Commission papers; and applicant and licensee documents and correspondence.

The following documents in the NUREG series are available for purchase from the NRC/GPO Sales Program: formal NRC staff and contractor reports, NRC-sponsored conference proceedings, and NRC booklets and brochures. Also available are Regulatory Guides. NRC regulations in the Code of Federal Regulations, and Nuclear Regulatory Commission Issuances.

Documents available from the National Technical Information Service include NUREG series reports and technical reports prepared by other federal agencies and reports prepared by the Atomic Energy Commission, forerunner agency to the Nuclear Regulatory Commission.

Documents available from public and special technical libraries include all open literature items, such as books, journal and periodical articles, and transactions. Federal Register notices, federal and state legislation, and congressional reports can usually be obtained from these libraries.

Documents such as theses, dissertations, foreign reports and translations, and non-NRC conference proceedings are available for purchase from the organization sponsoring the publication cited.

Single copies of NRC. draft reports are availahle frep upino willell request to the Division of Techl. nical Information and Document Control, U.S. Nuclear Regulatory Commission, Washington, DC 20555.

Copies of industry codes and standards used in a substantive manner in the NRC regulatory process are maintained at the NRC Library, 7920 Norfolk Avenue, Bethesda, Maryland, and are available there for reference use by the public. Codes and standards are usually copyrighted and may be purchased from the originating organization or, if they are American National Standards, from the American National Standards Institute, 1430 Broadway, New York, NY 10018. 

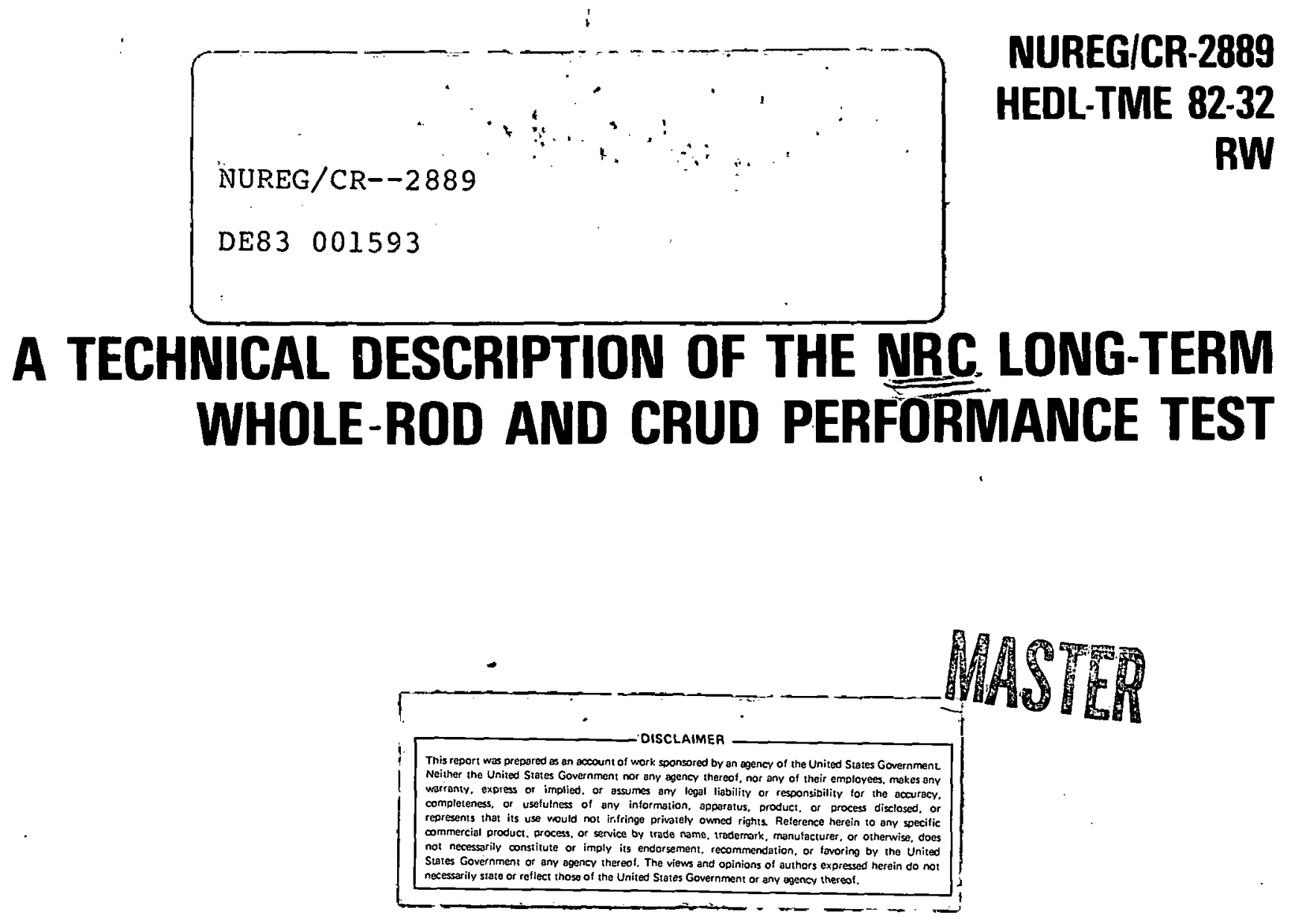

\section{Hanford Engineering Development Laboratory}

Uperated by Westinghouse Hanford Company P.O. Box 1970 Richland, WA 99352 A Subsidiary of Westinghouse Electric Corporation

R.E. Einziger

R.L. Fish

R.L. Knecht

Manuscript completed: August 1982 Date published: September 1982

Prepared for Division of Engineering Technology Office of Nuclear Regulatory Research U.S. Nuclear Regulatory Commission Washington, DC 20555 NRC FIN No. B2435 
THIS PAGE WAS INTENTIONALLY LEFT BLANK 
A TECHNICAL DESCRIPTION OF THE NRC

LONG-TERM WHOLE ROD AND CRUD PERFORMANCE TEST

\author{
R.E. Einziger \\ R.L. Fish \\ R.L. Knecht
}

\begin{abstract}
Westinghouse Hanford Company (WHC) and EG\&G-Idaho are jointly conducting a long-term, low-temperature, spentfuel, whole rod and crud behavior test to provide the Nuclear Regulatory Commission (NRC) with information to assist in the licensing of light water reactor (LWR) spent-fuel, dry storage facilities.

Readily available fuel rods from an $H . B$. Robinson Unit 2 (PWR) fuel assembly and a Peach Bottom-II (BWR) fuel assembly were selected for use in the 50-month test. Both intact and defected rods will be tested in inert and oxidizing atmospheres. A $230^{\circ} \mathrm{C}$ test temperature was selected for the first 10-month run. Both nondestructive and destructive examinations are planned to characterize the fuel rod behavior during the 5-yr test. Four interim examinations and a final examination will be conducted. Crud spallation behavior will be investigated by sampling the crud particulate from the test capsules at each of the four interim examinations and at the end of the test.

The background to whole rod testing, description of rod breach mechanisms, and a detailed description of the test are presented in this document.
\end{abstract}




\section{THIS PAGE}

\section{WAS INTENTIONALLY \\ LEFT BLANK}




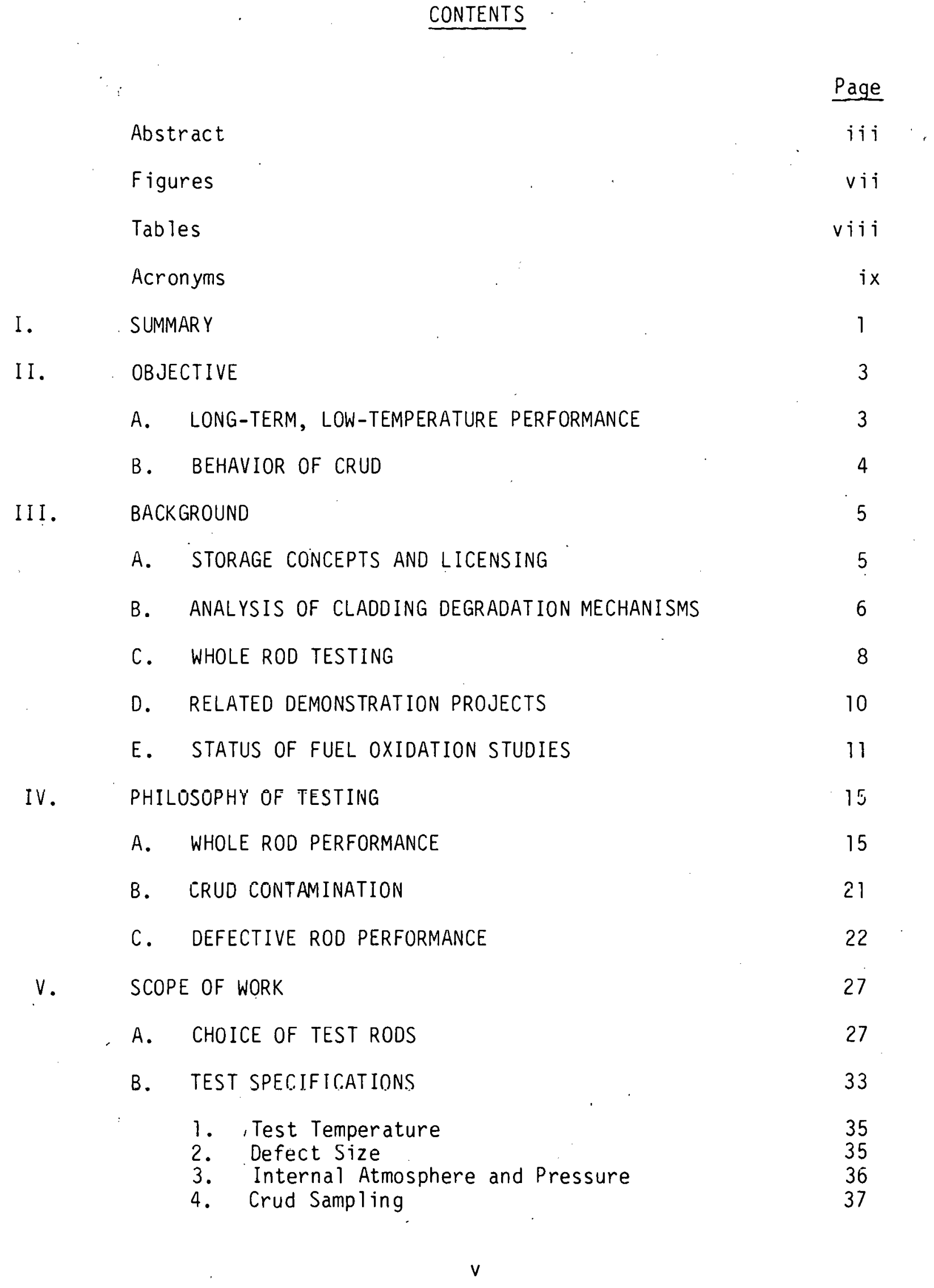




\section{CONTENTS (Cont'd)}

\section{HOT CELL' SPECIFICATIONS}

1. General Specifications

2. Specific Test Specifications

VI. EXPECTED RESULTS AND APPLICATIONS

VII. REFERENCES

APPENDIX A LEAK DETECTION

AHHENUIX B CLAUUING UXIUATIUN

APPENDIX C FUEL OXIDATION

APPENDIX $\bar{X}$ WEIGHING AS A MEANS TO STUDY FUEL

OXIDATION IN WHOLE ROD TESTS $\underline{\text { Page }}$

38

38

40

41

43

$A-1$

$B-1$

C-1

D-1 


\section{FIGURES}

Figure

Page

$1 \quad$ Oxidation of Defected Fuel Elements

14

2 Questions Concerning Breached Rod Behavior in Unlimited Air Storage Test at $230^{\circ} \mathrm{C}$

3 Characterization of H. B. Robinson Unit 2 Assembly B0-5

30

4 Characterization of Peach Bottom-II Assembly PH 462

32

C-1 Oxidation Front Length for 1-year Period at Temperature Based on Two Different Oxidation Rate Predictions

C -4 


\section{TABLES}

Table

1 Major Test Parameters of U.S. LWR Spent Fuel Storage Demonstrations and Whole Rod Tests

Nondestructive Examination Uses

3 Destructive Examination Uses

Comparison of LWR and CANDU Fue 1

Rods for the Low-Temperature, Whole-Rod Test

Tentative Test Specifications

$7 \quad$ Available Fuel Assemblies

8 Summary of Examinations Conducted on Fue 1 from H. B. Robinson Unit 2 Assembly BO-5 and Peach Bottom-II PH 462

A-1 Rod and Capsule Characteristics A-4

A-2 Fraction of Tracer Gas A-4

A-3 Detection Limits A-4

A-4 Leak Detection Limits for Helium Gas with

1\% Heliumin Argon Cover Gas A-6

B-1 Fuel Rod and Capsule Characteristics B-5

B-2 Capsule Air Pressure B-5

$\begin{array}{ll}C-1 & \text { Fuel and Storage Characteristics to Calculate Fuel } \\ \text { Oxidation Length } & C-6\end{array}$

D-1 Weight Change Measurements for $\mathrm{II}_{3} \mathrm{n}_{7}$ Formation . D-4

W-2 Weight Change Measurements for Determining $U_{3} 0_{8}$
Formation 


\section{ACRONYMS}

$\begin{array}{ll}\text { BCL } & \text { Battelle Columbus Laboratory } \\ \text { BWR } & \text { Boiling Water Reactor } \\ \text { CDF } & \text { Cumulative Damage Fraction } \\ \text { DE } & \text { Destructive Examination } \\ \text { DOE } & \text { Department of Energy } \\ \text { DSSD } & \text { Dry Surface Storage Demonstration } \\ \text { GE } & \text { General Electric } \\ \text { INEL } & \text { Idaho National Engineering Laboratory } \\ \text { LWR } & \text { Light Water Reactor } \\ \text { NDE } & \text { Nondestructive Examination } \\ \text { NRC } & \text { Nuclear Regulatory Commission } \\ \text { NTS } & \text { Nevada Test Site } \\ \text { ONWI } & \text { Office of Nuclear Waste Isolation } \\ \text { PCI } & \text { Pellet-to-Cladding Interaction } \\ \text { PWR } & \text { Pressurized Water Reactor } \\ \text { SCC } & \text { Stress Corrosion Cracking } \\ \text { TRA } & \text { Test Reactor Area } \\ \text { WHC } & \text { Westinghouse Hanford Company }\end{array}$




\section{A TECHNICAL DESCRIPTION OF THE NRC \\ LONG-TERM WHOLE ROD AND CRUD PERFORMANCE TEST}

\section{SUMMARY}

West inghouse Hanford Company (WHC) and EG\&G-Idaho are jointly conducting a long-term, low-temperature, spent-fuel, whole rod and crud behavior test to provide the Nuclear Regulatory Commission (NRC) with information to assist in the licensing of light water reactor (LWR) spent-fuel, dry storage facilities.

Readily available fuel rods from an H. B. Robinson Unit 2 pressurized water reactor (PWR) fuel assembly and a Peach Bottom-II boiling water reactor (BWR) fuel assembly were selected for use in the 50-month test. Both intact and defected rods will be tested in inert and oxidizing atmospheres. A $230^{\circ} \mathrm{C}$ test temperature was selected for the first 10-month run because of the reported uncertainty in temperature $\left(250 \pm 10^{\circ} \mathrm{C}\right)$ required for the formation of the $\mathrm{U}_{3} \mathrm{O}_{8}$ oxidation product from $\mathrm{UO}_{2}$ coupled with the temperature control instrumentation uncertainties of $\pm 10^{\circ} \mathrm{C}$. The intent is to test just below the temperature where significant quantities of $\mathrm{U}_{3} \mathrm{O}_{8}$ form in an unlimited air atmosphere. The test temperature will be raised just below $250^{\circ} \mathrm{C}$ for subsequent runs if the rod examination after the first run indicates that this is feasible.

Both nondestructive (NDE) and destructive examinations (DE) are planned to characterize the fuel rod behavior during the 5-year test. Four interim examinations and a final examillation will be conducted. Crud spallation behavior will be investigated by sampling the crud particulate from the test capsule at each of the four interim examinations and at the end of the test.

The background to whole rod testing, description of rod breach mecha$n$ isms, and a detailed description of the test are presented in this document. 


\section{THIS PAGE}

\section{WAS INTENTIONALLY \\ LEFT BLANK}




\section{OBJECTIVE}

The objective of this project is to provide the NRC with information to confirm or estabish spent-fuel, dry storage licensing positions relative to: 1) long-term, low-temperature $\left(<250^{\circ} \mathrm{C}\right)$ behavior of spent-fuel rods in dry storage and 2) radioactive contamination potential of crud from cladding for dry storage. The basic need for this data is to:

1) Confirm long-term, low-temperature $\left(<250^{\circ} \mathrm{C}\right)$, spent-fuel, dry storage performance predictions based on theoretical analyses and on results from high-temperature, short-term laboratory tests

2) Determine the nature and behavior of crud layers as a function of dry storage time

3) Determine the potential radioactive crud contamination (e.g., spalling, characteristics) for dry storage.

A. LONG-TERM, LOW-TEMPERATURE PERFORMANCE

Dry storage of spent fuel in unlimited air below $250^{\circ} \mathrm{C}$ is thought to be viable. This is based on a number of considerations:

1) If there is an unlimited air atmosphere, less than $10 \%$ of the cladding wall would be expected to oxidize in a 100-year storage period

2) Analyses and testing have indicated that below $250^{\circ} \mathrm{C}$ there are no expected cladding breach mechanisms for normal rods

3) For very conservative worst-case analyses, stress corrosion cracking (SCC) of the cladding is a possibility, but the only consequence should be a release of fission gas with no particulate fuel release due to the low temperature

4) Since rod breaches occurring in-reactor are not routinely identified and sorted out, it is assumed that some rods with pin hole breaches 
will enter dry storage; below $250^{\circ} \mathrm{C}$ the $U_{2}$ pellet, if in contact with air, oxidizes to $\mathrm{U}_{3} \mathrm{O}_{7}$ with little density change and, as a result, the fuel pellet (or pieces) structure is maintained and no stress is imposed on the cladding

Therefore, any study of the long-term, spent-fuel performance below $250^{\circ} \mathrm{C}$ should concentrate on three points:

- Determining if any unforeseen cladding breach mechanisms appear

- Relating fuel performance to the lifetime predictions based on SCC models

- Determining the long-term behavior of breached fuel rods

Both BWR and PWR spent fuel are being tested in the program because they represent the two major generic fuels in the spent fuel population.

\section{B. BEHAVIOR OF. CRUD}

The questions of concern regarding crud during dry storage are:

- Will it spall from the rods?

- Huw much crud will spall from the rods?

- Will respirable-size particulate occur?

- How radioactive is the crud?

To experimentally address these yuestions, the total dry storage cycle of loading the storage facility, the storage period, and the decommissioning must be considered. For the four generic types of storage (cask, silo, dry well and vault), the time frame of importance will be different. The program will attempt to answer the four questions about crud by determining crud contamination potential from specimens subjected to the environments seen during the three stages of the dry storage cycle. Both PWR and BWR rods will be included in the program. 


\section{BACKGROUND}

The WHC is providing the technical lead for a low-temperature, longterm rod and crud performance program using PWR and BWR spent fuel rods. Testing is being conducted by EG\&G-Idaho at the U.S. government facilities operated at the Idaho National Engineering Laboratory (INEL). This task is being performed for the NRC.

\section{A. STORAGE CONCEPTS AND LICENSING}

There are four main containment systems for dry storage of spent fuel presently under consideration by utilities: 1) vault, 2) cask, 3) dry well, and 4) silo. (1) These storage containment systems may have either active or passive cooling and provide for storage of rods either as intact assemblies or disassembled and consolidated, close-packed rod arrays. The two main differences between intact assemblies and close-packed rod configurations relative to fuel rod performance are a higher heat load per unit volume and the possibility of rod damage due to the consolidation process. Proper design of the containment system could ensure that maximum temperature limits will not be exceeded for the consolidated rods. The amount of cladding damage caused by consolidation is presently unknown, but should be established in the future. While in storage, the fuel performance depends only on the temperature and the atmosphere. The atmospheric composition and temperature limits in a particular storage mode will be governed to a great extent by the need to store breached fuel and the necessity to use a secondary canister. The economic penalty of the canister fabrication may be offset by the relaxation of the temperature and atmospheric requirements.

The NRC indicates three time periods of interest for these systems: fuel emplacement, storage, and decommissioning. (2) During these periods, the following conditions related to fuel performance must be satisfied: ( 2$)$ 
- The fuel cladding must be protected against degradation and gross rupture.

- There must be surveillance to ensure limiting conditions are met.

- There shall be adequate safety under normal and accident conditions.

- Releases to the environment shall be with in acceptable limits.

Potential fuel cladding degradation and breach mechanisms need to be evaluated and understood under a range of dry storage environmental conditions for these 1 icensing requirements to be met.

\section{B. ANALYSIS OF CLADDING DEGRADATION MELHANISMS}

Four degradation mechanisms have been identified ${ }^{(3)}$ that might cause cladding breach during dry storage: 1) stress-rupture, 2) SCC, 3) hydriding, and 4 ) external oxidation. While each of these potential breach mechanisms could be active under certain storage conditions, control of the spent fuel environment during storage can ensure that cladding breach will not occur.

Spent fuel rods are potentially susceptible to failure by stressrupture since the internal pressure in the rod produces a tensile hoop stress in the cladding wall. Factors generally contributing to shorter rod lifetimes due to stress-rupture are high lemperatures, high internal gas pressure and, incipient cracks in the cladding wall that might be produced in-reactor. While this mechanism was originally thought to be the most probable cause of breach, (3) high-temperature testing (4) has indicated that this may not be the case. At the temperatures be iny considered for dry storage, adititional data are required to confirm that 1 ifetimes based on stress-rupture exceed the anticipated 100-year storage period.

SCC, as an active degradation mechanisin in Zircaloy - clad fuel rods, is not well understood. (1) The corrosive environment responsible for SCC

OZircaloy is a registered trademark of Westinghouse Electric Corp., Specialty Metals Division, Blairsville, PA. 
in fuel rods comes from the fission products generated during irradiation. The specific agent causing SCC has not been positively identified, although iodine is thought to be the prime candidate. (5) Gamma radiolys is of solid $\mathrm{CsI}^{(6)}$ to produce localized iodine vapor [thought to be responsible for inreactor $\mathrm{SCC}(7)$ ] may not be active during storage, thus reducing. SCC effects. Presently available data seem to indicate that SCC will not be an active mechanism at the temperatures and cladding hoop stresses expected in dry storage.

Zircaloy hydriding has been a matter of concern for in-reactor fuel rod performance $^{(8)}$ and thus deserves attention with regard to storage. The primary storage concern relates to the orientation of the hydrides formed in-reactor. Proper processing of the Zircaloy during fabrication of the tubing and quality control of the moisture limits in the fuel pellets result in the in-reactor formation of an acceptable concentration of hydrides, which are circumferentially oriented. Reorientation of the hydrides during storage to a radial direction (perpendicular to the hoop stress) could result in severe degradation of the cladding mechanical properties. However, reorientation of hydrides usually requires high tensile stresses (9) and is, therefore, not likely to be active under expected storage conditions.

Oxidation of Zircaloy results in a brittle film, which is created at the expense of the relatively ductile base metal. The degradation of the cladding mechanical properties will dictate temperature and oxygen levels allowed during spent fuel storage. Cladding oxidation may limit the maximum storage temperature in an unlimited air atmosphere. Whole rod tests conducted in air will automatically incorporate the effects of oxidation on stressrupture behavior for the test time and temperatures. However, oxidation data must be generated for longer times to fully account for cladding oxidation effects.

Blackburn (3) analyzed each of the mechanisms discussed above and determined that stress-rupture was the most likely breach mode, although there was uncertainty about SCC. Blackburn's stress-rupture analys is was based on the $95 \%$ tolerance level of stress-rupture properties for unirradiated Zircaloy and assumed that the cumulative damage fraction (CDF) 
technique is valid. It did not allow for cladding crack development or synergistic oxidation effects. The model provided conservatism by assuming an internal rod pressure approximately two to three times that occurring in a normal PWR fuel rod and an engineering safety factor of about 1.5 on the cladding stress.

Based on his analysis, (3) Blackburn recommended a maximum allowable cladding temperature of $380^{\circ} \mathrm{C}$ for spent fuel storage in a nonoxidizing atmosphere. The limit is based entirely on stress-rupture considerations for spent PWR fuel assemblies; higher temperatures could be allowed using stressrupture considerations on ly for BWR fuel assemblies. Estimates of reliable maximum allowable temperatures based on SCC considerations were not possible because of the limited SCC data base and resulting uncertainties in the analysis. Further work to verify potential SCC effects was recommended.

C. WHOLE ROD TESTING

Blackburn's predictions ${ }^{(3)}$ are dependent on the validity of the underlying assumptions with regard to the breach mechanisms, as well as the cladding material properties and fuel rod physical condition. Direct verification of these predictions is not possible in a laboratory time frame. However, the predictions can be shown to be conservative by varying life interinal rod prcssure and/nr temperature. Experimentally, temperature is lhe easiest to vary; this also allows the internal environment of the intact irradiated rod to be preserved.

Originally, the cladding was considered part of the multibarrier system for the disposal of spent fuel. At $380^{\circ} \mathrm{C}$ cladding temperature, the package design was such that the temperature limits on the geology were not exceeded. Economically, it was feasible to use the highcst possible geology temperature; therefore, tests were conducted lu determine the maximum allowabls cladding temperature for spent fuel. Accelerated high temperature $\left(480^{\circ} \mathrm{C}\right.$ to $570^{\circ} \mathrm{C}$ ) tests were conducted ${ }^{(4)}$ on intact PWR rods (normal irradiated rod pressure of $350 \mathrm{psi}$ ) to determilie the dominant mode of cladding hreach and degree of cladding degradation. Since in-reactor irradiation hardening 
anneals quickly above $350^{\circ} \mathrm{C}$, the results obtained at the higher temperatures would have to be confirmed at the lower storage temperatures where the cladding would retain the irradiation hardening.

Test temperatures in the accelerated high temperature tests for the Office of Nuclear Waste Isolation (ONWI) were dictated by the desire to obtain cladding breaches in reasonable times ( $\leq 1$ year). Well characterized rods were used $(10-13)$ so that if breach did not occur, the extent of the degradation could be determined. The details of the tests have been previously described. (4) Normally, in a pressurized tube test, the pressure will remain constant and the cladding hoop stress will increase as the cladding creeps. In this test, the pressure and, hence, the cladding stress dropped as the cladding strained. This is due to the small volume of gas present and the fuel pellets occupying most of the internal rod volume. Cladding breach did not occur because of creep strain up to $15 \%$ and the resulting drop in stress. A number of physical changes or absence of physical changes were observed that ultimately affect cladding lifetime. These are:

- No detectable release of fission gas

- Cracking of the external oxide layer

- Formation of oxygen-stabilized alpha Zircaloy layer between the cladding and the $\mathrm{ZrO}_{2}$

- Penetration but blunting of cracks in the oxygen-stabilized alpha Zircaloy

- Large amounts of cladding creep

When these observations are factored into Blackburn's models, (3) a 100-year cladding lifetime based on the stress-rupture mechanism can be obtained by extrapolation using the Larson-Miller (14) technique for storage temperatures as high as $425^{\circ} \mathrm{C}$. This prediction is still based on unirradiated stress-rupture properties, which are probably representative above $370^{\circ} \mathrm{C}$. Below $350^{\circ} \mathrm{C}$, there will be incomplete annealing of the irradiation damage during the storage lifetime; therefore, the use of unirradiated stress-rupture properties and extrapolation of the higher temperature whole rod test results may be inappropriate. 
The United States Department of Energy (U.S. DOE) through the Commercial Spent Fuel Storage Program is initiating a whole rod test under the technical direction of WHC at Battelle Columbus Laboratory (BCL) to study performance below $350^{\circ} \mathrm{C}$ where minimal cladding anneal ing is expected to occur. Five characterized PWR fuel rods from Turkey Point Unit 3 are being tested for six months at $325^{\circ} \mathrm{C}$. The rods are being pressurized prior to testing to 21300 psia. The test will be used to provide a partial basis for establishing a minimum time/temperature relationship to describe spent fuel cladding integrity in terms of the cladding hoop stress for fuel storage in an unlimited air atmosphere. The Larson-Miller method ${ }^{(14)}$ will be used to relate the test data to longer times and different storage temperatures.

While the test at $325^{\circ} \mathrm{C}$ will give bounding information concerning $\mathrm{clad}-$ ding integrity with respect to the $\mathrm{SCC}$ and stress-rupture mechanisms, it will not be geared to study the overall rod performance over the wide range of atmospheric and rod conditions included in the present test.

\section{RELATED DEMONSTRATION PROJECTS}

While other types of fuel [metals, (15) carbides, (16) HTGR ${ }^{(16)}$ ] have been tested under dry storage conditions in large numbers, there have only been two small-scale $(17,18)$ demonstrations of LWR spent fuel dry storage tin the U.S. These are both being conducted at the Nevada Test Site (NTS) using PWR fuel from Turkey Point Unit 3. The fuel was extensively characterized $(10-13)$ prior to insertion into the tests. The decay heat rating ranged from 1 to $2 \mathrm{~kW} /$ assembly. The dry surface storage demonstration (DSSD) ${ }^{(17)}$ consisted of two assemblies in drywells and one assembly in a concrete sealed storage caisson. The test was started in early 1978. Storage temperatures were in the range of $150^{\circ} \mathrm{C}$. The $\mathrm{Climax}(18)$ spent fuel test consisted of eleven assemblies in the $\mathrm{Cl}$ imax mine. The test temperature was $\sim 250^{\circ} \mathrm{C}$ when the test started in early 1979.

Major test parameters of demonstration and whole rod tests are given in Table 1. The DSSD and Climax tests will demonstrate the feasibility of dry storage of spent fuel rods in intact assemblies. The NRC tests have a wider 
range of conditions and expand the source of rods used to establish a data base. Demonstration and whole rod tests are different ways of obtaining performance information. Both are expected to yield significant results although the whole rod tests are somewhat more controllable.

\section{E. STATUS OF FUEL OXIDATION STUDIES}

If a breached fuel rod is unknowingly placed in dry unlimited air storage or if a breach occurs in a fuel rod while in dry storage, fuel oxidation rather than cladding degradation may become the controlling mechanism for the release of contamination. This contamination can result from three sources:

- Particles of fuel breaking away from the pellet

- Gases released from the oxidized fuel

- Crud flaking off cladding

To determine the propensity for contamination, oxidation rates and oxidation products must be known.

It is inappropriate to state that there is some temperature above which $\mathrm{UO}_{2}$ oxidizes in air. $\mathrm{UO}_{2}$ oxidizes at all temperatures but the oxidation rate and final oxidation product are strongly temperature dependent. Numerous studies $(19-27)$ indicate that below about $250^{\circ} \mathrm{C}$, the $\mathrm{UO}_{2}$ oxidizes to $\mathrm{U}_{3} \mathrm{O}_{7}$, which has approximately the same nensity as $\mathrm{UO}_{2}$. Abovc $250^{\circ} \mathrm{C}$, the $\mathrm{UO}_{2}$ uxlulzes to $\mathrm{U}_{3} \mathrm{O}_{8}$, which has a much lower density. This lower density results in fuel swelling and a disruption of the fuel matrix. The majority of fuel oxidation studies have been conducted on very fine powders with a high surface area, $S A>1 \mathrm{~m}^{2} / \mathrm{g}$. Pellets were used only at high temperatures. The measurements on irradiated $\mathrm{UO}_{2}$ are not definitive enough to say whether oxidation rates are higher or lower $(28)$ than for unirradiated $\mathrm{UO}_{2}$. The most recent work on $\mathrm{UO}_{2}$ oxidation by Boase and Vandergraaf ${ }^{(29)}$ confirmed earlier work. 0xidation studies below $350^{\circ} \mathrm{C}$ included investigation of both powder and pellet fragments. The irradiated powders did not tend to show a higher oxidation rate than the unirradiated $\mathrm{UO}_{2}$. 


\section{TABLE 1}

MAJOR. TEST PARAMETERS OF U.S. LWR SPENT =UEL STORAGE DEMONSTRATIONS AND WHOLE ROD TESTS

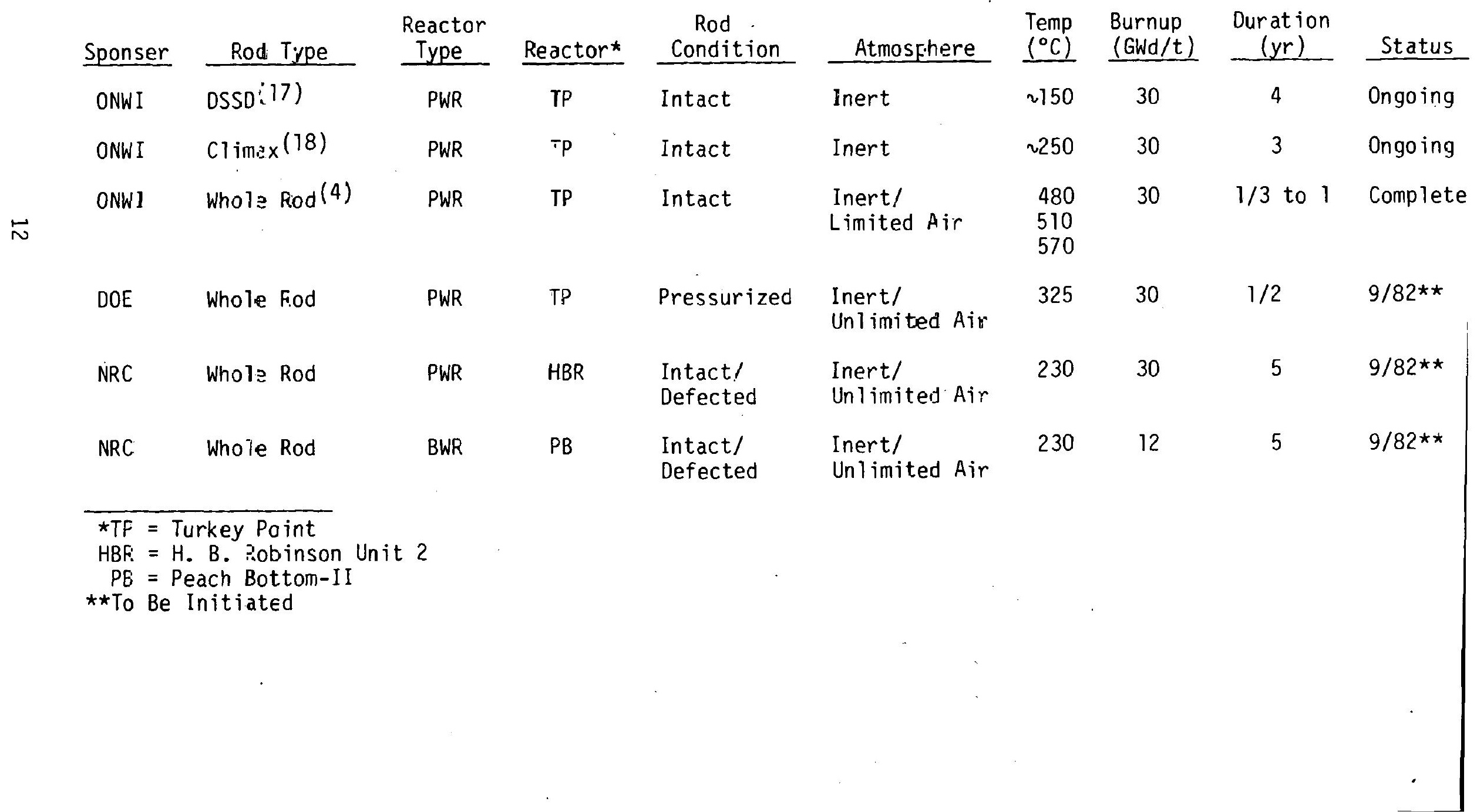


Boase and Vandergraaf ${ }^{(29)}$ investigated the results of fuel oxidation in a Canadian fuel element. Holes or slits were placed in the cladding of both irradiated and unirradiated rods. The rods were then placed in an oxidizing atmosphere between 250 and $375^{\circ} \mathrm{C}$. As expected, the fuel oxidized to $\mathrm{U}_{3} \mathrm{O}_{8}$, put a stress on the cladding due to the lower $\mathrm{U}_{3} \mathrm{O}_{8}$ density, and the hole in the cladding extended. The velocity of the fuel oxidation front was determined metallographically. At $300^{\circ} \mathrm{C}$, the oxidation front velocity and crack extension velocity are approximately equal. Once again, irradiated fuel tended to oxidize faster and the cracks extended faster. Boase and Vandergraaf's data, shown in Figure 1 , are not suitable for spent fuel performance predictions. First, the data are fit with a bilinear form with a break of slope at $2300^{\circ} \mathrm{C}$. The scatter in the data allows it to be fit equally well with a single linear fit since there is no physical reason to expect a break in the activation energy at $300^{\circ} \mathrm{C}$. Second, while there is no data below $250^{\circ} \mathrm{C}$, the higher temperature data are extrapolated through this temperature where oxidation products are known to change in order to make prediction about lower temperature behavior. Third, the holes and slits in the study were very large compared to that which would be expected in an undetected, in-reactor breach or in-storage SCC breach; thus, a continuous supply of oxygen to the fuel pellets is assumed. While the size of the defect should not matter at temperatures below $250^{\circ} \mathrm{C}$, above $250^{\circ} \mathrm{C}$ the ability of the defect to limit oxygen ingress would bias any results on fuel rod performance. The Boase and Vandergraaf ${ }^{(29)}$ data provide a starting point for calculdliuns of possible performance of defected rods. Such calculations are made in Appendix $C$. Additional data need to be generated to describe in more detail the fuel oxidation behavior below $250^{\circ} \mathrm{r}$. and in fuel rods that have tight stress-corrosion cracking type breaches. 


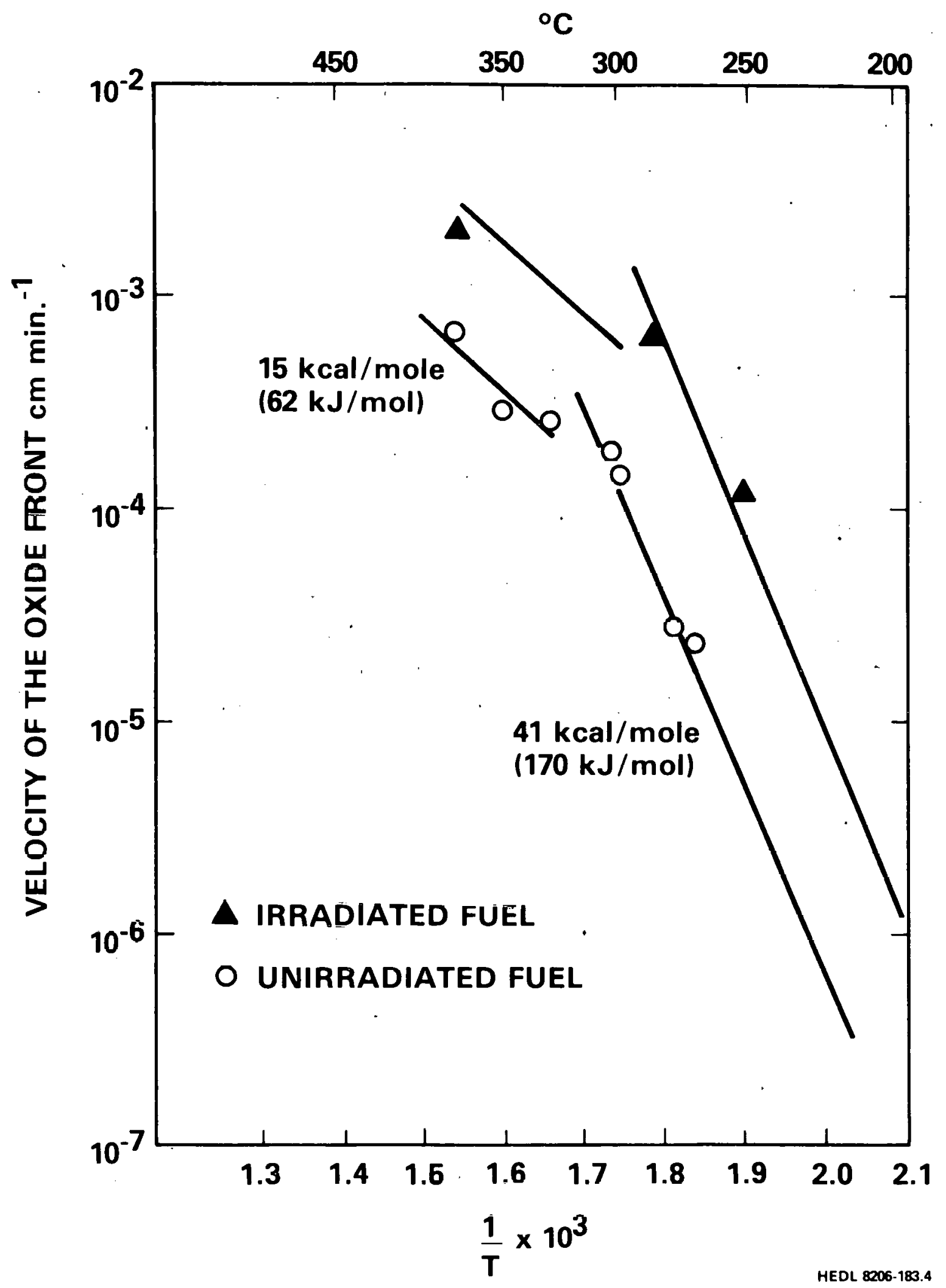

FIGURE 1. Uxidation of Defected Fuel Elements (velority of the oxide front vs $1 / T)(\operatorname{Ref} 28)$. Neg P13384-1 


\section{PHILOSOPHY OF TESTING}

\section{A. WHOLE ROD PERFORMANCE}

The whole rod tests represent an intermediate position between laboratory testing of small segments and demonstration testing of whole assemblies or groups of assemblies. In some instances, such as studying rod/hardware interaction, demonstration testing is clearly preferred. In other instances, such as well controlled breach inducement, laboratory testing is preferred. Since storage programs look for the weak link in rod performance, whole rod testing offers some distinct advantages:

- It is more economical than demonstration testing, which requires extensive facilities.

- One whole rod is equivalent in material volume to w24 laboratory samples.

- The complete rod, which has materials properties gradients along its length due to in-reactor temperature and fluence gradients, is tested.

- The internal atmosphere that controls many of the breach mechanisms in the rod is not disturbed.

- The test conditions can be controlled and varied more precisely than in a demonstration.

- Six whole rods are statistically equivalent to a whole as sembly. (30)

For these reasons, WHC views the whole rod test as the preferred method to study fuel rod performance for the stated objectives.

BWR rod segments have been tested in the laboratory but have never been part of a whole rod or demonstration test. This test will provide the first testing of BWR rods, which represent $240 \%$ of the spent fuel population. Although BWR rods operate with much lower internal pressure (2 to $10 \mathrm{~atm}$ ) and have a thicker cladding ( 0.032 in. to $0.045 \mathrm{in.}$ ) than PWR rods (20 to $30 \mathrm{~atm}$ and $0.022 \mathrm{in.}$ to $0.030 \mathrm{in}$. cladding), the BWR rods have approximately 
the same breach statistics as PWR rods. (31) The BWR rods also tend to release more fission gas; ${ }^{(32)}$ hence, more corrosive fission products accumulate in the rod gap, at least in the unpressurized BWR vintage, than in the PWR rods. Thus, the BWR fuel rods have some attributes that make them more susceptible to breach and other attributes that make them less susceptible to breach. This test will compare BWR and PWR rod performance directly in both inert and oxidizing atmospheres. It is important to know the initial condition of the material being tested. Both NDE and DE may be necessary. The type of information gained from each of these examinations is given in Tables 2 and 3 . The NDE provide information on gross changes in the rod condition while DE enables the detection and measurement of smaller or slow, subtle changes that might be taking place. For example, examining rods for gross changes occurring in-reactor, NDE is most often used consisting of only an eddy current examination or a visual. Or, for example, in whole rod testing, NOE is useful where gross changes such as excessive creep are expected; but the more significant information is expected to be that determined by $D E$, e.g., metallography, ceramography, hardness testing, etc.

Examinations to be used on the rods in this test were selected on the basis of the resources available and how best to meet the test objectives (each of which requires a differenl initial fuel rod characterization):

1) To determine the rontamination potential and performance of deferted rods

2) To determine the degradation potential of intact whole rods

3) To determine the contamination potential due to spallation of crud from the r.ladding surface

Contamination from a defected rod can originate from three sources:

- Oxidation of the fuel pellet, which disrupts the grain structure and releases fission gas residing on the grain boundary

- Splitting of the cladding due to stress imposed by the oxidizing fuel and fallout of the fuel particulate from the split cladding

- Spallation of crud due to the cladding strain or other factors 
TABLE 2

NONDESTRUCTIVE EXAMINATION USES

Visual

Gross Cracks

Crud Condition

General Rod Condition

Rod Length

Profilometry

Cladding Dilation

Pellet/Cladding Mechanical

Interaction
Eddy Current

Large Incipient Cracks

Breaches in $\mathrm{UO}_{2}$ Water-Inundated Rods

Gross Pellet Cladding Interaction

Oxide Thickness with Specialized EC

Gamma Scan

Fluence Profile

Gross Pellet Condition

Fuel Column Height

Fuel Pellet Gap

Crud Profiles with Some Scanners

TABLE 3

DESTRUCTIVE EXAMINATION USES

Fission Gas Analyses

Fission Gas Release

Cladding Stress

Internal Rod Volume

Metal lography

Hydride Urientation

Cracks in Cladding

Oxide Thickness

Fuel Cladding Chemical Interaction

Diffusion Zones

Crud Thickness

Grain Size
Ceramography

Grain and Void Size Pellet

Pellet Cracking

Fuel Cladding Chemical Interaction

Mechanical Property

Hardness-Anneal ing

Strength

Ductility

Embrittlement

Fusion Analys is

Gas Content in Cladding

Burnup Analys is

17

Burnup 
Hence, information is needed on three rod features:

- Physical condition of the fuel pellet

- Extent of cladding splitting

- Crud spallation

The condition of the pellet can be measured by using gamma scanning to look for loss of the pellet-to-pellet interface peaks. Since the absence of interface peaks on the gamma scan output is a gross change in the fuel, a pretest gamma scan is not needed. Splitting of the cladding requires visual knowledge of the breach site prior to testing, hence, a visual examination is required. The excessive spallation of the crud is a comparative result with the spallation from intact rods and, as described in a later section, will be measured at each interim test. Therefore, to accomplish objective 1, "Determine the contamination potential and performance of defected rods," the only necessary pretest examination is visual inspection of defected rods.

To determine the degradation potential of intact rods requires assurance that the rods are intact. Although the individual test rods from the H. B. Robinson Unit 2 assembly have not been eddy current examined, over 20 companion rods have been examined and only one of those rods showed any suspect area; hence, while it would be preferable to have eddy current on the H. B. Robinson Unit 2 rods, there is sufficient characterization of the assembly to preclude the need for eddy current examination of the actual test rods. All of the Peach Bottom-II rods have undergone both ultrasonic testing and eddy current testing, and General Electric has confirmed in writing that all the test rods are sound.

Since the results from higher temperature whole rod tests indicate that the performance at $230^{\circ} \mathrm{C}$ should be benign $(4)$ and the amount of expected cladding creep $(33-37)$ is below the detectable limits of present profilometers, profilometry is not needed. Eddy current examinations will not be conducted during the first interim examination but will be conducted during the second and subsequent examinations to detect possible crack growth. An 
unbreached rod should have no mechanism for gross fuel pellet oxidation to $\mathrm{U}_{3} \mathrm{O}_{8}$; hence, there should be no gross changes in the gamma spectrum received from the fuel pellet itself. A visual examination should be conducted to ensure that the general condition of the rod is not changing.

As indicated in Table 3, the DE give useful information about small changes in the cladding and fuel behavior. Therefore, there should be a good $D E$ data base prior to testing. This data base already exists for the H. B. Robinson Unit 2 fuel rods and no further pretest DE is needed. The Peach Bottom-II destructive characterization is weak and should be enhanced with additional metallography/ceramography, fusion analys is and hardness testing, which can be done after the first destructive interim examination on samples set aside for this purpose in an inert atmosphere. To satisfy Objective 2, "Determine the degradation potential of intact whole rods," a visual examination of the rods is necessary along with the additional oE of Peach Bottom-II fuel.

To accomplish Objective 3, "Determine the contamination potential due to spallation of crud from the cladding surface," knowledge concerning the crud condition on the rods is required. This will be established with a combination of visual examinations and DE. The visual will provide an overview of the crud on the rod. The $D E$ will include metallography to look at crud adherence and crud removal to establish both the chemical composition and volume of crud. Results of the crud removal will allow a pretest gamma scan spectrum to be determined so that the crud can be followed starting at the first interim examination.

After characterization, each rod is placed in an individual capsule. By proper choice of the atmosphere and pressure in the capsule, the whole assembly performance can be simulated and the breach detection enhanced. This is difficull, if not impossible, in whole assemblies where tight breaches many times go undetecteil. In the present case, since the interild capsule pressure is not being continuously monitored, argon with $1 \%$ helium was chosen as the capsule fill gas to provide an inert atmosphere and to 
allow leak detection. Sufficient air pressure will be placed in the other capsules to simulate an unlimited air atmosphere.

Based on the results of other whole rod tests $(4)$ and laboratory studies, $(24,38)$ the performance of whole intact rods in either an inert or oxidizing atmosphere is expected to be benign at $230^{\circ} \mathrm{C}$. No cladding creep, (33-37) gas release from the pellets, $(39,40)$ or breaches are expected. It is not anticipated that any changes will be observed in the tests; but to verify that this is the case, interim examinations will be conducted each year on the rods. These will include:

- Gas analyses of the capsule atmosphere to determine if breaches occurred

- Crud collection and visual examination to assess crud spallation

- Gamma scanning for changes in the crud structure and pellet structure

- After the second and fifth year, a DE of one rod for any cladding annealing, excessive cladding oxidation or other changes in the cladding or pellets that would indicate noticeable or conceivable degradation of the fuel rod over a 100-year storage period

In whole rod tests designed to follow specific expected physical phenomena, the test duration is set so that the phenomena will be measurable hased on current knowledge. Five years provides a reasoriable testing time frame for a number of reasons:

1) Four interim examinations and a final examination should provide a sufficient number of measuremenls lo determine the rate of any detected changes taking place.

2) A 5-yr teil covers the prrind of greatest. temperature drop. Spent fuel still generates $24.2 \mathrm{~kW} /$ assembly (PWR) or $1.4 \mathrm{~kW} /$ assembly (BWR) one year after removal from the reactor. (41) If an assembly was placed into storage at this time, after 5-years storage the same assembly would generate $20 \%$ of the initial power. (41) Since the temperature of the 
rods will be proportional to the heat generation, the temperatures should have dropped substantially from the initial storage drop.

3) Very slow rate phenomena significant relative to 100 years should be detectable in 5 years. Continuation of the test is possible should that be desirable.

Although the optimum way to describe the behavior for 100 years is to store or test for 100 years, this is not practical. The 5-yr test provides data in a reasonable time frame and could provide lead test rods for future surveillance if the test results dictate the necessity.

\section{B. CRUD CONTAMINATION}

The NRC requirements in 10 CFR 72(2) that relate to spent fuel behavjor for dry storage system licensing are summarized in the background section of this report. Each requirement or condition has been specified to minimize release of radioactive contamination from the fuel rod. Release of radioactive crud from the surface of the fuel rod by spallation or other mechanisms is, therefore, of concern and should be addressed as an integral part of the whole rod performance program. Information generated with regard to the quantity and nature of crud released from fuel rods under conditions anticipated for dry storage facilities will provide needed information for the design and licensing of these facilities.

Crud is largely a mixture of hematite $\left(\mathrm{Fe}_{2} \mathrm{O}_{3}\right)$ and magnetite $\left(\mathrm{Fe}_{3} \mathrm{O}_{4}\right)$ that deposits from the coolant water on the exterior of the cladding. It may contain some fission products or actinides, which were released to the coolant due to gross, in-reactor breaches and from residual fuel in the coolant/ fuel system. Crud thereby poses a potential source of radioactive contamination from spent fuel throughout the storage cycle. Crud deposits range from a dense adherent layer to a flaky porous layer. 
To assess crud release during storage, specific knowledge of the fuel rod crud prior to emplacement in the facility is required. Studies to assess the nature of crud on both PWR and BWR fuel rods have been conducted. $(42-45)$ These studies will provide a partial basis and guidance for the elements that should be present in the crud on the test rods. Specific quantitative measurements and analyses of the character and radioactivity of the crud will be conducted on companions to the test rods to provide an initial condition for the crud behavior aspect of the test. In addition, four interim examinations and a final examination over a 5-year period will provide information on the crud spallation behavior of the test rods as a function of time. The examinations will include collection of crud from the test capsules as well as from filters placcd in line with a gas sampling bottle. Quantitative determinations on the collected particulate will be made including radioactivity measurements. The spallation rate as determined by these examinations will provide a bas is for extrapolation of the crud behavior to longer storage periods. The extrapolation of crud quantities and calculation of radioactivity levels will provide needed information for design and licensing of spent-fuel, dry storage facilities.

\section{DEFECTIVE ROD PERFORMANCE}

It is anticipated that even with in-reactor pool sipping, some assemblies that contain rods with pinhole SCC bredches will be placed in dry storage. The behavior of these breached rods will depend on the size of the breach, storage atmosphere, and storage temperature.

If the rods are stored in an inert atmosphere container that does not leak, the behavior should be benign (whether the breach is large or smal1) since there is no mechanism to change the characteristics of the fuel pellet. A larye crack can be defincd as one which allows the free ingress of oxygen and outgress of fissiun gases but does nul allow pellet partiring or fragments to leave the rod. A gross breach can be defined as one that would allow pellet particles or fragments to mechanically dislodge from the rod. 
If the rods are stored in an oxidizing atmosphere, then the storage temperature and possibly the size of the breach becomes important to determine rod behavior. Pertinent questions relative to test and storage at a temperature $<50^{\circ} \mathrm{C}$ are given in Figure 2. The ultimate question in each case is: "Will the cladding split open releasing fuel particulate contaminants and how fast?" Even if oxidation to $U_{3} D_{8}$ occurs a long time after storage initiates, the $\mathrm{U}_{3} \mathrm{O}_{8}$ has a lower density than $\mathrm{UO}_{2}$ and, hence, will result in fuel pellet expansion and stressing of the cladding. The Canadians (29) found in CANDU fuel that above $250^{\circ} \mathrm{C}$ a relatively large (1-mm) initial defect propagated to expose more fuel. Differences between the Canadian fuel rods and the U.S. LWR fuel rods are given in Table 4. The LWR fuel has a cladding wall approximately twice the thickness of the Canadian fuel, so the cladding stress will be half. In any fuel though, a considerable cladding strain would result from fuel oxidation from $\mathrm{UO}_{2}$ to $\mathrm{U}_{3} \mathrm{O}_{8}$ and there is a distinct possibility that above $250^{\circ} \mathrm{C}$, the cladding will split if $0_{2}$ contacts the fuel pellet.

For a large crack, $\mathrm{O}_{2}$ will come in contact with the fuel. Above $250^{\circ} \mathrm{C}$, $\mathrm{UO}_{2}$ will oxidize to $\mathrm{U}_{3} \mathrm{O}_{8}$. The major question is whether or not the cladding stress is sufficient to split the cladding. Below $250^{\circ} \mathrm{C}$, the literature seems to indicate that the stable reaction product is $\mathrm{U}_{3} \mathrm{O}_{7}$. There is some question as to whether $\mathrm{U}_{3} \mathrm{O}_{7}$ is the final reaction product below $250^{\circ} \mathrm{C}$ or if the reaction kinetics for the $2 U_{3} 0_{7}+0_{2}+2 U_{3} O_{8}$ are so slow that tests have not been conducled fur Lime perlods long enough to observe $\mathrm{U}_{3} \mathrm{O}_{8}$. If $\mathrm{U}_{3} \mathrm{O}_{7}$ is the stable reaction product, then there should be no detrimental rod behavior, since the density of $\mathrm{U}_{3} \mathrm{O}_{7}$ and $\mathrm{UO}_{2}$ are nearly the same and there would be little if any stress on the cladding.

If the breaches are SCC-type tight cracks, there are additional questions. Can the $0_{2}$ penetrate the breach? Will corrosion products close the opening? If the answer is yes, then storage of rods with SCC-type breaches in an oxidizing atmosphere above $250^{\circ} \mathrm{C}$ might be possible. 


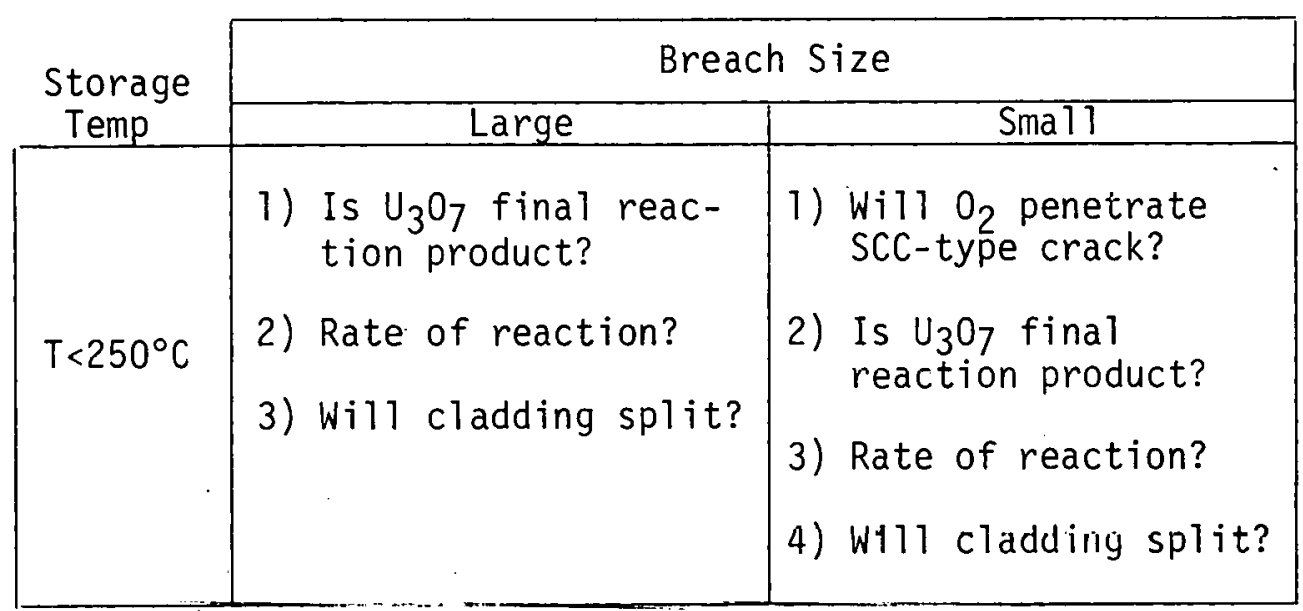

FIGURE 2. Questions Concerning Breached Rod Behavior in Unl inited Air Storage Test at $230^{\circ} \mathrm{C}$.

TABLE 4

COMPARISON OF LWR AND CANDU FUEL

Fuel Characteristic

Fuel density $(g / c c)$

Pellet diameter $(\mathrm{mm})$

Gap (mm)

Wall thickness (mim)

Smear density

Cladding strain necessary to accommodate fue 1 swelling $(\%)$
BWR $\quad$ PWR $\quad$ CANDU

$\begin{array}{lll}10.3 & 10.3 & 10.6\end{array}$

$\begin{array}{lll}12.4 & 9.29 & 14.25\end{array}$

$\begin{array}{lll}0.25 & 0.18 & 0.08\end{array}$

$\begin{array}{lll}0.81 & 0.62 & 0.38\end{array}$

$\begin{array}{lll}0.87 & 0.87 & 0.95\end{array}$

$\begin{array}{lll}10.1 & 10.0 & 12.4\end{array}$ 
The current study will examine the behavior of rods with large defects (large defects are used since placing SCC-type cracks in a whole rod is impractical at the present time) in inert and oxidizing atmospheres. As described previously, the test in argon is expected to be benign. The rod will be examined visually to look for crack growth and gamma scanned to look for fuel relocation indicative of the $\mathrm{UO}_{2}$ to $\mathrm{U}_{3} \mathrm{O}_{8}$ conversion. Gas release from the pellets will also be used as a method of detecting pellet geometric disruption. Filters will be placed at the end of each capsule to collect the airborne oxide particles that might exit the rod if $\mathrm{U}_{3} \mathrm{O}_{8}$ forms. Weight change measurements have also been suggested, based on Canadian work, to measure the rate of fuel oxidation. Weight change measurements are analyzed in Appendix 0 and are shown not to be suitable. The Canadian (29) measurements may have been possible due to the much smaller rods, which allow a more sensitive in-cell balance to be used.

In summary, the primary thrust of breached whole rod performance is to determine over a time frame accounting for the largest temperature drop in the fuel rod:

- Any unforeseen degradation during storage in an inert atmosphere

- Amount of cladding degradation due to fuel oxidation (i.e., cladding splitting)

- Dispersal of particulate, especially respirable particulate, if cladding splitting occurs 


\section{THIS PAGE}

\section{WAS INTENTIONALLY \\ LEFT BLANK}




\section{SCOPE OF WORK}

Eight rods covering the eight conditions encompassed by the combinations of rod type (BWR or PWR), atmosphere (inert, unlimited air) and rod condition (intact, defected) are to be tested (see Table 5). Two additional rods were chosen for initial crud analysis. The choice was based on initial evaluation of characterization data. The rods will be tested according to the specifications in Table 6 and periodically examined for rod and crud performance. This section provides the basis for rod selection and test specifications along with a description of the associated hot cell work.

\section{A. CHOICE OF TEST RODS}

The cost of obtaining LWR fuel from reactor sites is high due to transportation costs. A survey of available fuel stored at EG\&G indicates that adequate fuel is available. There are presently five assemblies in the EG\&G TAN Facility storage pool. Pertinent data for these assemblies are given in Table 7. H. B. Robinson Unit 2 fuel appears to be a "normal" PWR assembly as borne out by rod characterization. (46) The Dresden fuel did not undergo any unusual reactor operations, but it is a very old fuel design not at all typical of present-day BWR fuel. Two out of nineteen Peach Bottom-II assemblies were found leaking via sip testing. Pellet-to-cladding interaction (PCI) and hydriding breaches were found in the assemblies with the PCI being much more severe in the unimproved fuel type. The breaches were apparently caused by control rod manipulation not in accordance with the fuel vendor's fuel preconditioning recommendations. The characterization data on rods from these assemblies, was gathered and rods selected for the test after analysis. No characterization was done on Assembly E-00161.

The H. B. Robinson Unit 2 assembly is well characterized in all aspects (see Figure 3 ). Generally, there is little variation in characteristics over the cross section of the assembly. Extensive eddy current traces showed no indication of any cladding incipient cracks. Based on the characterization in the literature, any of the rods would probably be suitable for the 
TABLE 5

RODS FOR THE LOW-TEMPERATURE, WHOLE-ROD TEST

\begin{tabular}{|c|c|c|c|c|c|}
\hline $\begin{array}{l}\text { Reactor } \\
\text { Type } \\
\end{array}$ & Reactor $\star$ & $\begin{array}{l}\text { Assembly } \\
\& \text { Rod No. }\end{array}$ & $\begin{array}{c}\text { Rod } \\
\text { Condition } \star \star \\
\end{array}$ & $\begin{array}{l}\text { Capsule } \\
\text { Atmosphere }\end{array}$ & $\begin{array}{c}\text { Capsule } \\
\text { Pressure } \\
023^{\circ} \mathrm{C} \\
\text { (psi absolute) } \\
\end{array}$ \\
\hline PWR & HBR & $B 0-5-08$ & Intact & $\mathrm{Ar}+1 \% \mathrm{He}$ & $15 \pm 1$ \\
\hline PWR & HBR & $B 0-5-G 7$ & Defected & $\mathrm{Ar}+1 \% \mathrm{He}$ & $15 \pm 1$ \\
\hline BWR & PB2 & PH 462-E5 & Intact & $\mathrm{Ar}+1 \% \mathrm{He}$ & $15 \pm 1$ \\
\hline BWR & PB? & $\mathrm{PH}$ 162-D6 & Defected & $\mathrm{Ar}+1 \% \mathrm{He}$ & $15 \pm 1$ \\
\hline PWR & HBR & $B 0-5-B 8$ & Intact & Air & $15 \pm 1$ \\
\hline PWK & $\mathrm{HBK}$ & $B \bar{U}-5-E T$ & Defected & Aip. & $\begin{array}{l}\text { Openl causule } \\
\text { with filters }\end{array}$ \\
\hline BWR & PB2 & PH 462-E4 & Intact & Air & $15 \pm 1$ \\
\hline BWR & PB2 & PH 462-E3 & Defected & Air & $\begin{array}{l}\text { Open capsule } \\
\text { with filters }\end{array}$ \\
\hline PWR & HBR & $B 0-5-J 7$ & Crud & $-\cdots$ & -- \\
\hline BWR & PB2 & PH 462-E6 & Crud & --- & -- \\
\hline
\end{tabular}

\footnotetext{
*HBR $=$ H.B. Robinson Unit 2

PB2 $=$ Peach Bottom-II

$\star \star$ Intact $=$ No through-cladding cracks

Defected $=$ will have mechanically machined breach

Crud = Rod to be cut for crud examination
} 


\section{TENTATIVE TEST SPECIFICATIONS}

Parameter

Test Temperature First Run

Test Temperature Later Runs

Test Duration

Rate of Temperature Rise

Rate of Temperature Drop

Temperature Monitoring

Electronically

Manually

Defect Size

\section{Specification}

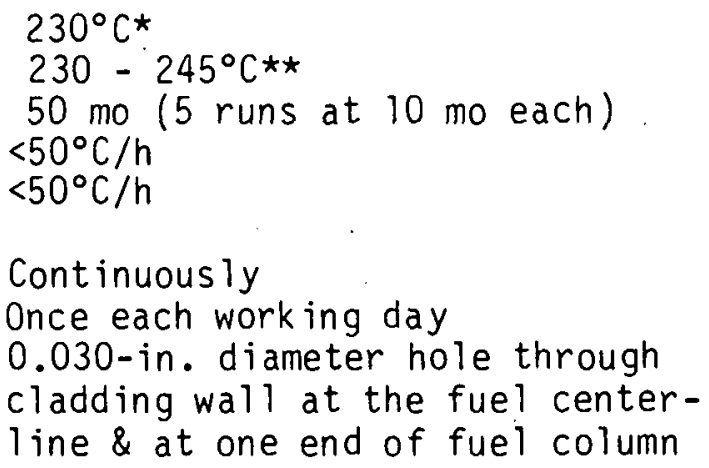

* Test temperature of $230^{\circ} \mathrm{C}$ was arrived at considering the range of uncertainty $\left(240\right.$ to $\left.260^{\circ} \mathrm{C}\right)$ associated with the $\mathrm{UO}_{2} \rightarrow \mathrm{U}_{3} \mathrm{O}_{8}$ conversion and uncertainties in the temperature control equipment $\left(+10^{\circ} \mathrm{C}\right)$.

$\star \star$ Exact temperature depends on results of first run inter $\bar{m}$ rod NDE.

TABLE 7

AVAILABLE FUEL ASSEMBLIES

Reactor*
Type
Array
Discharge Date
Burnup (GWd/t)
Power Level

$(\mathrm{W} / \mathrm{cm})$

Cladding

Rod Pressurized

EG\&G Coffin

Initial

Enrichment (\%)

Rods Available

Fuel Column Length (in.)

Other

\begin{tabular}{|c|c|c|c|c|}
\hline \multicolumn{5}{|c|}{ As sembly } \\
\hline $\mathrm{BO}-5$ & PH 462 & $\mathrm{PH} 006$ & $E-00161$ & UN0064 \\
\hline & PB2 & PB2 & Dr 1 & Dr 1 \\
\hline PWR & BWR & BWR & BWR & BWR \\
\hline $15 \times 15$ & $7 \times 7$ & $7 \times 7$ & $6 \times 6$ & $6 \times 6$ \\
\hline $5 / 71$ & $3 / 76$ & $3 / 76$ & $2 / 73$ & $8 / 75$ \\
\hline 30.5 & 12.9 & 9.5 & 19.8 & 23.8 \\
\hline 230 to & 330 & 330 & -- & $\ldots$ \\
\hline
\end{tabular}

175

Zry-4 Zry-2 Zry-2 Zry-2 Zry-2

Yes No No No No

$\begin{array}{lllll}C & A & B & D & H\end{array}$

1.9 to 2.5 avg 1.1 avg 1.83 .1 .79 to

3.1

138

33

37

28

2.34

11

144

144

144

108

108

Design

$\star H B R=H . B$. Rob inson Unit 2

PB2 = Peach Bottom-II

Drl $=$ Dresden 1 
ZDA = CONTROL ROD

$I=$ INSTRUMENT TUBE

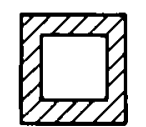

$=$ NRC TEST ROD

BU = BURNUP ANALYSIS

$V=V I S U A L$
$P=$

P = PROFILOMETRY
EC = EODY CURAENT

FM = FUEL METALLOGAAPHY

CM = CLAODING METALLOGAAP

9 OTHER RODS NOT AVALABLE

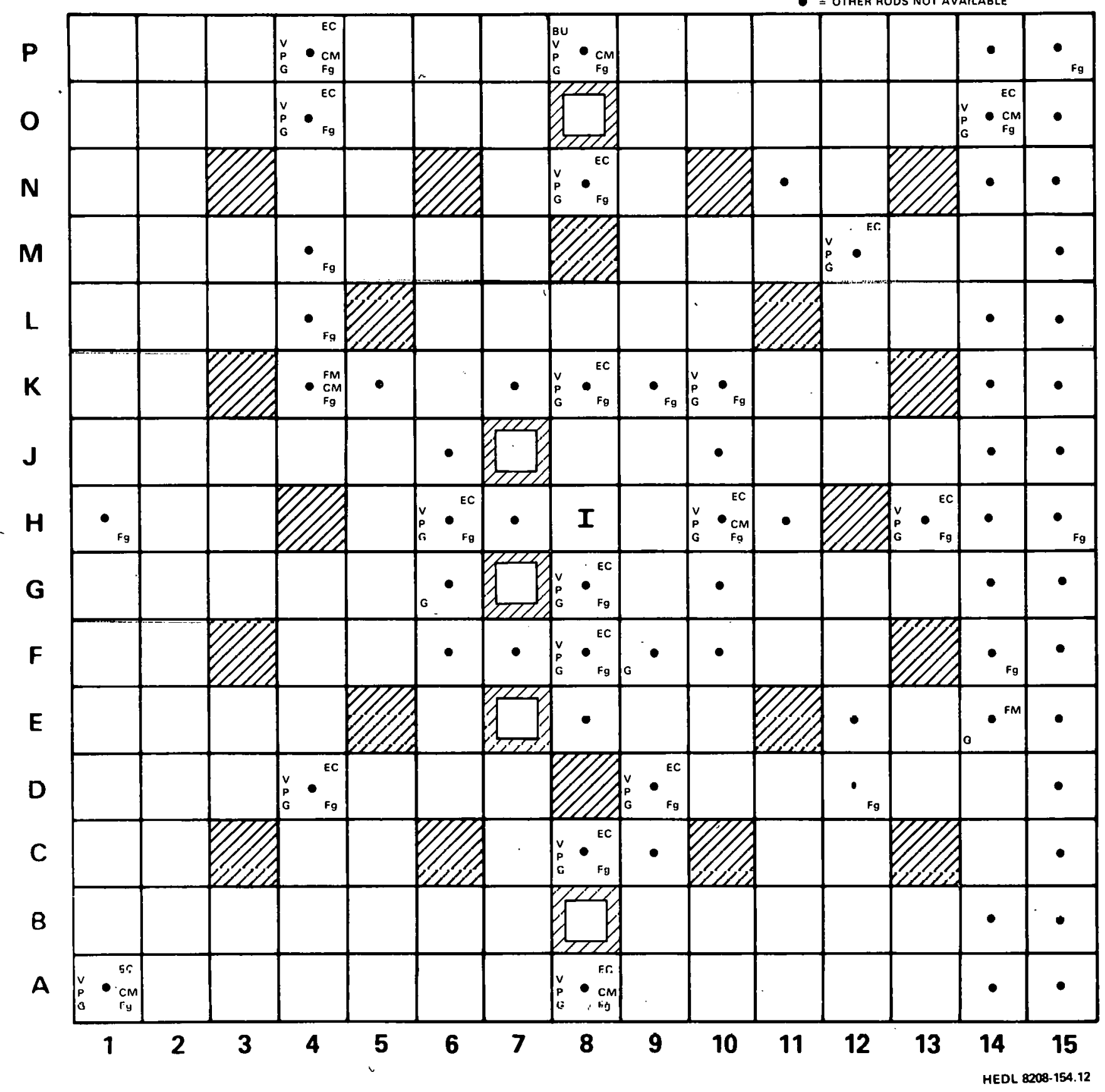

FIGURE 3. Characterization of H. B. Robinson Unit 2 Assembly B0-5. 
NRC testing purposes. The five rods picked for the test are shown by location in the assembly in Figure 3. Rods, which are to remain intact were picked from positions away from control rods and bounded by we 11 characterized rods. The rod to be cut for initial crud analysis was chosen central to the assembly where it would not receive coolant edge effects.

Although the Dresden assemblies represented the higher burnup BWR fuel, no fuel was chosen from the two Dresden assemblies. This was for a number of reasons:

- The assemblies are either not characterized or only minimally characterized.

- Only edge rods are available in the assembly with some characterization.

- This is a very old fuel design with shortened fuel rods.

- The fuel rods are 1 to 3 yr older than the Peach Bottom-II fuel.

The amount of characterization on both Peach Bottom-II assemblies is approximately equal. Two rods have had fission gas analyses, and metallography was done on one or two rods (see Figure 4). All the rods have undergone eddy current inspection at poolside. General Electric has stated that eddy current inspection showed no incipient crack indications in any rods except those that breached. Assembly PH 462 was chosen to supply the rods since it: 1) had the higher burnup of the two Peach Bottom-II assemblies, 2) contained improved fuel more similar to the standard $8 \times 8$ fuel now used, and 3) had a higher enrichment. The lower burnup $(12 \mathrm{GWd} / \mathrm{t}$ vs $25 \mathrm{GWd} / \mathrm{t}$ burnup presently attained) of the Peach Bottom-II fuel is not of major concern since:

1) Irradiation hardening, yield strength, and ultimate strength of the cladding has saturated; hence, additional burnup should not change the mechanical properties of the cladding. 


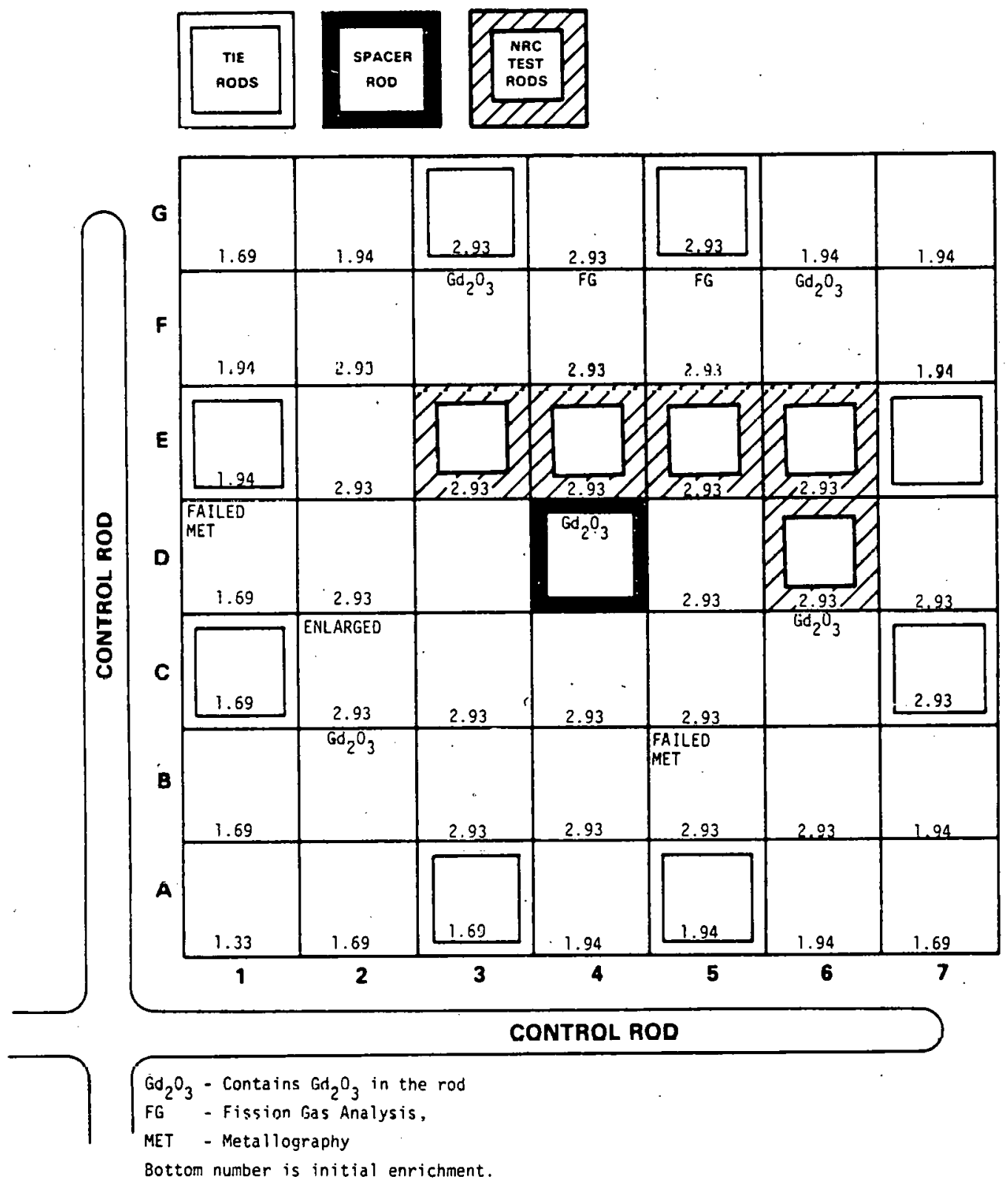

FIGURE 4. Characterization of Peach Bottom-II Assembly PH 462. 
2) Gas release is already higher than would be the case for a modern vintage $8 \times 8$ rod. Modern pressurized BWR fuel has a gas release of $<1 \%$ up to $25 \mathrm{GWd} / \mathrm{t}$. The Peach Bottom-II fuel had a ga's release of almost $3 \%$. Since the fission product release is approximately proportional to the burnup, if one considers the volume of the fuel and surface area of the cladding, the Peach Bottom-II rods have an internal fission product concentration that is nearly the same as a pressurized rod from an $8 \times 8$ assembly.

3) The in-reactor breach of rods is usually associated with power transients, not burnup. The Peach Bottom-II assemblies underwent reactor operations that are unusually severe for BWR assemblies.

Care was taken not to choose tie rods, spacer rods, or gadolinium rods for testing. Tie rods and spacer rods, while identical to other rods in fuel configuration, are either too long or too wide for testing purposes. Gadolinium rods are different than normal fuel rods due to a mixture of $\mathrm{Gd}_{2} \mathrm{O}_{3}$ with the $\mathrm{UO}_{2}$. Since these assemblies had in-reactor problems due to control rod insertions, test rods were picked from the region of the assembly away from the control rod blade. Since the assembly has a multizoned enrichment, the test rods were chosen to have the same enrichment as the characterized rods. Within these constraints, there are only eight rods available. There is no particular justification for the five picked from the group of eight. The position of the five rods is shown in Figure 4 .

A summary of the characterization examinations performed on fuel rods from assemblies selected for the dry storage test is presented in Table 8. Initial characterization recommendations are also summarized in Table 8.

\section{B. TEST SPECIFICATIONS}

Test specifications include test temperature, rate of rise-totemperature, rate of drop-from-temperature, monitoring of test, capsule atmosphere and pressure, and defect sizes. The rate of rise-to-temperature, 
SUMMARY OF EXAMINATIONS CONDUCTED ON FUEL FROM $H$. B. ROBINSON UNIT 2 ASSEMBLY BO-5 AND PEACH BOTTOM-II ASSEMBLY PH 462

\begin{tabular}{|c|c|c|c|c|}
\hline Reactor & Assembly & Type of Test & $\begin{array}{l}\text { No. of } \\
\text { Tests } \\
\end{array}$ & $\begin{array}{c}\text { Initial Recommended } \\
\text { Characterization } \\
\end{array}$ \\
\hline \multirow[t]{4}{*}{ HBR } & BO-5 & NDE & & \\
\hline & & $\begin{array}{l}\text { Visual } \\
\text { Eddy Current } \\
\text { Profilometry } \\
\text { Gamma Scan }\end{array}$ & $\begin{array}{l}18 \\
18 \\
18 \\
22\end{array}$ & Visual on Each Test Rod \\
\hline & & $\underline{D E}$ & & \\
\hline & & $\begin{array}{l}\text { Fissiun Gas And lys is } \\
\text { Burnup Analys is } \\
\text { Fuel Ceramography } \\
\text { Claddinq Metallography }\end{array}$ & $\begin{array}{r}20 \\
2 \\
3 \\
7\end{array}$ & Crud Characterization \\
\hline \multirow[t]{4}{*}{ PB2 } & PH 462 & NDE & & \\
\hline & & $\begin{array}{l}\text { Eddy Current } \\
\text { Visual }\end{array}$ & $\begin{array}{r}49 \\
2\end{array}$ & Visual on Each Test Rod \\
\hline & r & $\underline{D E}$ & & \\
\hline & & $\begin{array}{l}\text { Fissionn Fas Analysic } \\
\text { Cladding Metallography }\end{array}$ & $\begin{array}{l}2 \\
2\end{array}$ & $\begin{array}{l}\text { Burnup Analys is, Cladding } \\
\text { Metallography \& Fuel } \\
\text { Cermography, Crud Charac- } \\
\text { terization }\end{array}$ \\
\hline
\end{tabular}


rate of drop-from-temperature, and monitoring of the test are the same as was used in the successful high-temperature, whole-rod test. (4) The rest of the specifications were set after analyses of the following concerns:

- Breach detection sensitivity

- Cladding oxidation

- Fuel oxidation

- Cladding annealing

- Effects of possible excursions

- Measurement tolerances

The conclusions of the analyses of these concerns are presented here. Further details are found in the appendices.

\section{Test Temperature}

It is desirable to operate the test at the highest possible temperature yet have some assurance that the $\mathrm{UO}_{2}$ will not convert to $\mathrm{U}_{3} \mathrm{O}_{8}$ during the test. A general literature survey $(99-27)$ indicates that $\mathrm{UO}_{2}$ converts to $\mathrm{U}_{3} \mathrm{O}_{8}$ above $250 \pm 10^{\circ} \mathrm{C}$. Below this temperature, $\mathrm{UO}_{2}$ converts to $\mathrm{U}_{3} \mathrm{O}_{7}$. The errors on the temperature controlling system are: controllers $\left( \pm 5^{\circ} \mathrm{C}\right)$, thermocouples $\left( \pm 2.5^{\circ} \mathrm{C}\right)$, and zero point compensators $\left( \pm 0.5^{\circ} \mathrm{C}\right)$. Combining these possible temperature errors with a lower bound on the $U_{3} 0_{8}$ formation temperature leads to a test temperature of $230^{\circ} \mathrm{C}$. If the first interim NDE indicates satisfactory rod performance, the temperature for subsequent runs will be raised but still remain $<250^{\circ} \mathrm{C}$.

\section{Defect Size}

Four rods will be defected with a 0.030-in. diameter hole drilled at the centerline and at one end of the fuel column in the fuel rod. Care will be taken to just penetrate the cladding. The defect will be photographically characterized prior to testing. These holes will represent large defects in the cladding as compared to SCC-type cracks. 


\section{Internal Atmosphere and Pressure}

Four rods will be tested in a dry inert atmosphere and four rods in an unlimited cell air atmosphere. The inert atmosphere was chosen based on leak detection capabilities. The unlimited air tests were divided into two groups: 1) intact rods enclosed in capsules with sufficient air supply so the oxygen won't be depleted by cladding oxidation and 2) defected rods in open capsules with filters on both ends.

There are no provisions for on-line monitoring of the capsule pressure or gas composition; therefore, if a breach vccurs, it will not be detectcd until the end of a run. There are three detectable gases in the fuel rods: xenon, krypton and helium. If helium is used as the capsule gas, urly xemuli and krypton can be used as leak detectors. With a 1-atin capsule pressure, a $1.8 \%$ gas leak would be detectable in the H. B. Robinson Unit 2 rods. A smaller breach would be detectable in the Peach Bottom-II rods due to the lower initial fill pressure. If argon is used for a capsule gas and helium as the leak detection gas, the size of a detectable leak is decreased by two orders of magnitude. For this reason, argon is used as fill gas with $1 \%$ helium in the inert capsules. See Appendix A for details of leak detection.

Two in-line filters will be connected in series at both ends of each test capsule open to the cell atmosphere. Selection of particulate filters was based on observed fuel particle sizes of 8 to $11 \mu \mathrm{m}$ that were ejected from ruptured fuel rods. (47) A $15-\mu m$ filter will be used to catch large particulate and allow fuel particles similar to those observed by Lorenz to pass through. A 2-um filter will be placed at the exit to collect all of the particles that pass through the $15-\mu \mathrm{m}$ filter.

The two intact rods need to be placed in a closed capsule, otherwise there is no way of detecting a breach. As calculated in the appendix, even at an upper test temperature of $250^{\circ} \mathrm{C}$, only $\sim 1$ atm of air is needed to accommodate cladding oxidation in the closed air without significantly depleting the oxygen. Uuring the course of the test, $<0.02 \%$ of the cladding should be oxidized. Should a breach occur in a closed capsule containing air, the 
maximum possible extension of the fuel oxidation front should be no more than 1 inch. Whether all the oxygen is depleted during the remainder of that run depends on the time in the run when breach occurs and the kinetics of fuel oxidation.

\section{Crud Sampling}

One Peach Bottom-II (BWR) fuel rod and one H. B. Robinson Unit 2 (PWR) fuel rod that were companions to the test rods will be cut into three equal segments each, maintaining longitudinal orientation and identification. These fuel rod segments will be shipped to the EG\&G Test Reactor Area (TRA) for crud analysis.

At the TRA hot cells, 8-in. sections will be designated and cut from each of the two fuel rods. The remaining fuel rod segments should be stored in an inert atmosphere for subsequent examination needs. The crud will be either scraped, chemically removed, or machined from a known area over the entire surface along at least $3 \mathrm{in}$. of each section. All of the crud will be collected from this operation. The following measurements and examinations will be conducted on the crud from each section:

- Radioactive measurement (gamma-beta and alpha)

- Weight and volume determination

- $G e\left(L_{1}\right)$ gamma detection for composition

- Physical characteristics, e.g., adhesion, particle size, color, composition, etc.

Collection of all particulate from the test capsules at each interim examination and at the end of the test will be used to establish the quantity and rate of crud spallation. Care will be taken to collect all particulate from the test capsules. This will be accomplished by dumping the capsule contents (after rod removal) intu a clean container and wipirly the inside of the capsule with a swab. Collection of the particulate from the capsule filters will ensure that all of the particulate is accounted for in 
the analysis. The radioactivity measurement, weight and volume determination, and $\mathrm{Ge}(\mathrm{Li})$ gamma analysis for composition will be conducted on each of the crud samples from the capsules and filters.

Based on the data generated from the measurements on the crud samples, calculations will provide a quantitative assessment of the total, initial amount of crud on each type of fuel rod (PWR and BWR), its chemical composition, and radioactivity level. In addition, crud spallation quantities measured at each interim will provide the basis for establishing spallation rates and a predictive model for extrapolation purposes. Together with the radioactivity measurements and calculations, the model can be used to assess the impact of spallation during the dry storage of spent fuel in light of radiuactive contamination.

\section{HOT CELL SPECIFICATIONS}

The general hot cell test specifications and some of the specific test specifications are given in the following:

\section{General Specifications}

The whole rod testing program will be conducted by EG\&G in the TAN Facility hot cells under the techmical dircction of WHC to determine the long-term, low-temperature behaviur of both intact and breached rods in air and inert atmospheres. In addition, the behavior of crud in a static situation will be determined. Intact rods presently in the EG\&G TAN Facility storage pooi [H. B. Robinson Unit 2 (PWR) and Peach Bottom-II (BWR)] will be moved into the TAN hol shop. Elghl rods will be precharacterized by a visual examination. Two PWR rods arld two BWR rods will he defected with small holes. These rods plus two intact PWR rods and two intact BWR rods make up the test loadiny. The rods will then be placed in individual capsules of a whole rod furnace test rack, backfilled with air or argon/1\% helium to a specified pressure, and leak checked or capped with filters, then inserted into the furnace. The furnace will be brought to a specified temperature 
$\left(230^{\circ} \mathrm{C}\right)$ over a two-day startup period and controlled to within $\pm 5^{\circ} \mathrm{C}$ for the duration of the test. Dual and independent over-temperature shutdown protection will be provided. Manual monitoring of the test rack temperatures will be conducted every working day. While at temperature, ten evenly spaced axial thermocouples will be monitored.

Five 10-month test runs will be conducted. At the end of each run, gas samples will be taken from each capsule and analyzed for xenon and/or helium as a double check for small rod leaks. Between runs, the rods will be removed for visual inspection of the rods in general and defects in particular and $\gamma$-scanning of selected rods; smears and crud collection will be conducted on the encapsulation tubes. The radioactive species present in the crud and an approximate measure of the crud quantity will be determined. At the completion of two years of test time, the intact BWR rod in an inert environment will be withdrawn for metallographic/microstructural analys is to determine any change in fuel rod materials conditions. Such DE for determining active degradation mechanisms is absolutely necessary to use these tests as predicting tools for longer term rod performance. It is expected that there will be no significant degradation mechanisms discovered by the examinations, and the seven remaining rods will continue under test. This will include the yearly visual inspection of the rod and defect sites, gamma scanning and crud evaluation tasks, and the completion of the tests with DE of selected rods. Should a significant degradation mechanism be found at any time, WHC will make an evaluation and recommendations for program modification to the NRC.

Concurrent with the first whole rod run, laboratory analyses will be conducted on two companion rods to establish the initial state of the crud. Samples will be taken along the length of the rod. These segments will be abraded over a known area to dislodge all the crud. The crud will be collected and counted in a Ge(Li) detector to determine the quantities of radioactive species present. These data will he used to establish the total amount of crud on the rods at the start of the whole rod test. 
2. Specific Test Specifications

During the course of the experimentation, examination and operation, specifications for the following work will be issued:

I - Pretest Rod Examination and Capsule Preparation

II - Furnace Qualification Loading: Cycle 1 Operation

III - TRA Crud Removal and Examination

- First Interim NOE

- Cycle 2 Operation

- Second Interim NDE

- Replacement Rod Pretest Charactcrization

- First DE

- Cycle 3 Operation

- Third Interim NDE

- Cycre 4 Operation

- Fourth Interim NDE

- Cycle 5 Operation

- Final NDE

- Final DE

- Final Crud Removal and Examination

- Waste Disposa?

Whenever possible, techniques used in other whole rod tests and standard hot cell procedures will be followed.

The current specific test specifications issued are: I - Pretest Rod Examination and Capsule Preparation and II - Furnace Qualification Loading: Cycle 1 Operation. 


\section{EXPECTED RESULTS AND APPLICATIONS}

The most likely first mode of spent fuel storage will be in an inert atmosphere at a relatively low temperature, 200 to $250^{\circ} \mathrm{C}$. There may be some undetected breaches placed in storage. There is a desire on the part of a number of utilities to relax the requirement of an inert atmosphere and use unlimited air storage. The present test was designed to allow the NRC to assess the feasibility and licensability of spent fuel dry storage under such conditions. Critical to this assessment is the measurement of crud spallation and the observation of cladding or fuel degradation or no degradation by NDE and DE. Other tests have been designed to accelerate possible degradation mechanisms by the use of increased temperature and pressure $(14)$ or to study the behavior of casks and drywells $(14-18)$ with minimal monitoring of the fuel behavior.

The present test will fill the void between the accelerated tests and demonstration tests by periodically ( $1-y r$ intervals) examining the condition of spent fuel stored under expected or postulated conditions for a period of time long enough to allow the storage temperature to drop significantly after emplacement $(5 \mathrm{yr})$. Particular attention will be paid to contamination that might be caused by fuel and fission product loss through defects and spalling of the exterior crud layer.

Past studies $(3)$ and tests $(4)$ indicate that after the 5 -yr period, those rods that were initially intact should remain intact with either the air or inert atmosphere. The DE of the test rods should confirm that immeasurable degradation of the cladding or fuel pellet has taken place. Annealing of the irradiation hardness, cladding grain growth, hydride reorientation, stabilized alpha Zircaloy growth, or excessive oxidation are not expected to take place. No additional gas or fission products are expected to be released from the pellet to the rod plenum. 
It is also expected that those defected rods stored in the inert atmosphere will have benign performance. No fallout of the fuel or oxidation of the fuel is expected. The expected results from the defected rods in the unlimited air atmosphere are somewhat more tentative. Significant literature ${ }^{(19-21)}$ indicates these rods should also have benign performance, but there is uncertainty cast on the expected performance by the uncertainty in the oxidation kinetics of $\mathrm{UO}_{2}$ and some recent Canadian work. (29) While this test is not designed to study the oxidation kinetics of $\mathrm{UO}_{2}$, the visual and gamma-scan examinations should give insight into the rate at which $\mathrm{UO}_{2}$ converts to $\mathrm{U}_{3} \mathrm{O}_{8}$, if indeed it does.

The behavior of the external crud on fuel rods has not been considered in detail in previous tests. With the use of fliters and silledrs, the present test should determine at what rate crud spalls from the rod and if respirable particulates are formed. Because of the uncertainties and lack of pertinent data, no predications are made with regard to the results of this aspect of the test.

The fuel rod decay heat drops by $80 \%$ during the first 5 yr of storage. The present test will allow NRC to determine if satisfactory performance can be accomplished for this period of time. The combination of NDE and DE will allow projections of probable performance past the 5-yr time frame. The work on the defected rods will help the NRC specify the degree of surveillance that might be necessary during dry storage to determine the necessity of secondary canisterization below $250^{\circ} \mathrm{C}$. 


\section{REFERENCES}

1. R. T. Anderson, Scoping Studies of the Alternative Options for Defueling, Packaging, Shipping and Disposing of the TMI-2 Spent Fuel Core, AGNS-35900-1.5-79, Allied General Nuclear Services, Barnwe11, SC, September 1980.

2. Code of Federal Regulations, "Licensing Requirements for the Storage of Spent Fue 1 in an Independent Spent Fuel Storage Installation, "Title 10, Part 72, and Radwaste News 1, p. 234, December 1980.

3. L. D. Blackburn, D. G. Farwick, S. R. Field, L. A. James and R. A. Moen, Maximum Al lowable Temperature for Storage of Spent Nuclear Reactor Fuel, HEDL-TME 78-37, Hanford Engineering Development Laboratory, Richland WA, May 1978.

4. R. E. Einziger, S. D. Atkin, D. E. Stellrecht and V. Pasupathi, "High Temperature Postirradiation Materials Performance of Spent Pressurized Water Reactor Fuel Rods Under Dry Storage Conditions," Nucl. Technol. 57, p. 65, April 1982.

5. D. Cubicciotti and R. 'L. Jones, EPRI-NASA Cooperative Project on StresS Corrosion Cracking of Zircaloys, EPRI NP-717, Electrical Power Research Institute, Pato Atto, CA, March 1978.

6. D. Cubicciott $i$ and J. A. Davies, "The Release of Iodine from Iodide Salts by Gamma Radiolysis," Nuc1. Sci. Eng. 60, p. 314, 1976.

7. D. Cubicciotti, R. L. Jones and B. C. Syrett, Stress Corrosion Cracking of Zircaloys, EPRI NP-1329, Electrical Power Research Institute, Palo Alto, CA, March 1980.

8. D. 0. Pickman, "Internal Cladding Corrosion Effects," Nucl. Eng. Des. 33, p. $141,1975$.

9. D. 0. Pickman, "Properties of Zircaloy Cladding," Nucl. Eng. Des. 2il, p. 212, 1972 .

10. R. B. Davis, Data Report for the Nondestructive Examination of Turkey Point Spent FueT Assemblies B02, B03, B17, B4T and B43, HEDL-TME 79-68, Hanford Engineering Development Laboratory, Richland, WA, May 1980.

11. S. D. Atk in, Destructive Examination of 3-Cycle LWR Fuel Rods from Turkey Point Unit 3 for the Climax - Spent Fuel Test, HEDL-TME 80-89, Hanford Engineering Development Laboratory, Richland, WA, June 1981.

12. R. B. Davis, Pre-Test Nondestructive Examination Data Summary Report on Turkey Point Spent Fuel Assemblies D01, 004, D06 for the Climax Spent Fuel Test, HEDL-TME 80-83, Hanford Engineering Development Laboratory, Richland, WA, June 1981. 
13. R. B. Davis and V. Pasupathi, Data Summary Report for the Destructive Examination of Rods G7, G9, J8, 19 and H6 from Turkey Point Fuel Assemb Ty BT7, HEDL-TME 80-85, Hanford Engineering Development Laboratory, Richland, WA, Apri 11981 .

14. F. R. Larson and J. Miller, "A Time-Temperature Relationship for Rupture and Creep Stresses," Trans. Am. Soc. Mech. Eng. 74, p. 765, 1952.

15. E. O. Maxwel1 and D. Deacon, "Dry Storage of Irradiated Magnox Fuel in Air," Nucl. Eng. Int., p. 71, May 1979.

16. P. A. Anderson and H. S. Meyer, Dry Storage of Spent Nuclear Fuel - A Preliminary Survey of Existing Technology and Experience, NUREG/CR-1223, Nuclear Regulatory Commission, Washington, DC, Apri] 1980.

17. R. J. Bahorich, "Spent Fuel Encapsulation and Ury Storage Deiñonstra tion," Trans. Am. Nuc1. Soc. 34, p. 834, 1980.

18. L. D. Ramspotts et al., Technical Concept for a Test of Geological Storage of Spent Reactor Fuel in the Climax Granite, Nevada Test Site, UCRL-52796, University of California, Radiation Laboratory, Berkeley, CA, 1979.

19. T. Smith, Kinetics and Mechanism of the Oxidation of Uranium Dioxide and Uranium Dioxide Plus Fissia Sintered Pellets, NAA-SR-4677, North American Aviation, Inc., Downey, CA, November 1960.

20. K. A. Peakall and J. E. Antill, "Oxidation of Uranium Dioxide in Air at 350-1000 C," J. NuCl. Mater. 2, No. 2, pp. 191-195, 1960.

21. R. E. DeMarco, H. A. Heller, R. C. Abbott and W. Burkhardt, "Oxidation of $\mathrm{UO}_{2}$ to $\mathrm{U}_{3} \mathrm{O}_{8}$," Ceramic Bulletin 38, No. 7, p. 360, 1959.

22. M. J. Bannister, "The Storage Behavior of Uranium Dioxide Powders Review Article," J. Nucl. Mater. 26, pp. 174-184, 1968.

23. M. Iwasaki, T. Sakurai, N. Ishikawa and Y. Kobayashi, "Öxidatiun uf $\mathrm{UO}_{2}$ Pellets in Air - Effects of Heat-Treatment of Pellet in Particle Size Distribution of Powders Produced," J. Nucl. Sci. and Technol. $\underline{5}$, No. 12, p. 652, December 1968.

24. S. Aronson, R. B. Ronf and J. Belle, "Kinetic Study of the Oxidation of Uranium Dioxide," J. Chem. Phys. 27, No. 1, p: 13\%, July 1957.

25. H. Ohashi, E. Noda, T. Morozume, "Oxidation of Uranium Dioxide," J. Nuc1. Sci. \& Technol. 11, No. 10, p. 445, October 1974. 


\section{REFERENCES (Cont'd)}

26. K. T. Harrison, C. Padgett and K. T. Scott, "The Kinetics of the Oxidation of Irradiated Uranium Dioxide Spheres in Dry Air," J. Nucl. Mater. 23, p. 121, 1967 .

27. H. Landspersky and M. Voboril, "Oxidation of $\mathrm{UO}_{2}$ Containing Small Additions of Other Oxides," J. Inorg. Nucl. Chem. 29, p. 250, 1967.

28. 3. Schmets, Pretreatment of Irradiated Fuels, "Quarterly Report 14, July 1 - September 30, 1963, EURAEC-884, US-EURATOM Joint Research and Development Program, 1963.

29. D. G. Boase and T. T. Vandergraaf, "The Canadian Spent Fuel Storage Canister Some Materials Aspects," Nucl. Technol. 32, p. 60, January 1977.

30. A. K. Miller, K. D. Challenger and A. Tasooji, SCCIG: A Phenomenological Model for Iodine Stress Corrosion Cracking of Lircaloy, Vol. T, EPRI NP-1798, Volume 1, Electrical Power Research Institute, Palo Alto, CA, April 1981.

31. F. Garzarolli, R. Von Jan and H. Stehle, "The Main Causes of Fuel Element Failure in Water Cooled Power Reactors, "Atomic Energy Review 17, No. 1, p. 31, 1979.

32. J. T. A. Roberts et al., LWR Fuel Performance Program: Progress in 1978, "EPR I NP-1024-SR, ETectrical Power Research Institute, Palo Alto, $\overline{\mathrm{CA}}$, February 1979.

33. D. A. Woodford, "Creep Analys is of Zircaloy-4 and Its Application in the Prediction of Residual Stress-Relaxation, "J. Nucl. Mater. 79, p. $345,1979$.

34. H. E. Rosinger and P. C. Bera, "Steady-State Creep of Zircaloy-4 Fuel Cladding from 240 to $1873 \mathrm{~K}, "$ J. Nucl. Mater. 32, p. 286, 1979.

35. D. L. Hagrman, G. A. Reymann and R. A. Mason, MATPRO-Version 11, A Handbook of Materials Properties for Use in the Analyses of Light Water Reactur Fuel Rud Beliavior, NUREG/CR-0497, Nuclear Regulatory Commission, Washington, DC, February 1979.

36. K. R. Merckx, "Calculational Procedures for Determining Creep Collapse of LWR Fuel Rods," Nucl. Eng. Des. 31, p. 95, 1974.

37. P. J. Pankaskie, Irradiation Effects on the Mechanical Properties of Zirconium and Dilute Zirconium Alloys: A Review, BN-SA-618, p. 47, Battelle Memorial Institute, Columbus, OH, JuTy 1976. 


\section{REFERENCES (Cont'd)}

38. F. L. Yaggee, R. F. Mattas and L. A. Neimark, Characterization of Irradiated Zircaloys: Susceptibility to Stress-Corrosion Cracking, EPRI NP-1155, Electric Power Research Institute, Palo Alto, CA, September, 1979.

39. W. L. Baldewicz, The State-of-the-Art of Fission Gas Release from LWR Fuels, UCLA-ENG-7740, University of California, School of Eng. \& App. Sci., Los Angeles, CA, May 1970.

40. K. Taketani and K. Ikawa, "Release of Xenon from Sintered $\mathrm{UO}_{2}$ at Low Temperatures," J. Nucl. Sci. Technol. 4, №. 12, p. 589, December 1967.

41. Disposal of Spent Nuclear Fuel, ONWI-59, Officc of Nuclear waste Isolation, December 1979.

42. Postirradiation Examination of Oconee 1 Fuel-Cycle 1 Destructive Test Phase, BAW-1535, Babcock and Wilcox, Lynchbura, VA, July 1979.

43. D. H. Lister, Crud Deposits on Zircaloy Clad Fuel, AECL-6962, Atomic Energy of Canada Ltd, Chalk River, Ontario, Canada, March 1980.

44. G. E. Zima, Comments on Fuel Crud as a Safety and Operational Factor of Independent Spent Fuel Storage Installation (ISFSI), PNL-2657, Pacific Northwest Laboratory, Richland, WA, November 1978.

45. N. Fuhrman et al., Evaluation of Fuel Rod Performance in Maine Yankee Core I, Final Report, EPRI NP-218, Project 586-1, Electrical Power Research Institute, Palo Alto, CA, November 1976.

46. S. J. Daybjartsson, B. A. Murdock, D. E. Owens and P. E. MacDonald, Axial Gas flow in Irradiated PWR Fuel Rods, IKEE-NUREG-1158, Nuclear Regulatory Commission, Washington, DC, September 1977. EG\&G.

47. R. A. Lorenz et al., Fission Product Release from Highly Irradiated LWR Fuel, ORNL/NUREG/TM-287, Oak Ridge National Laboratory, Oak Ridge, TN, February 1980. 
A P PENDIX A

LEAK DETECTION

$A-1$ 
THIS PAGE

\section{WAS INTENTIONALLY LEFT BLANK}

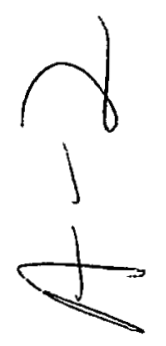




\section{LEAK DETECTION}

There are two ways to detect if a leak occurs in a rod during a run:

- Pressure rise in the capsute

- Mass spectrographic analysis of the capsule gas

Since the capsule pressure is going to be monitored only at the beginning and end of each run and since the mass spectrographic method is more accurate, only the mass spectrographic method will be considered further.

Let $y$ be the volume of gas in the capsule and $M$ be the fraction of tracer gas in the rod. If $V r$ is the total gas in the rod of which a fraction ( $f$ ) leaks out, then the total gas in the capsule after the leak is $y+f V r$. The total amount of tracer gas in the capsule is fMVr. Therefore, the percentage of tracer gas in the capsules

$$
\frac{f M V r}{y+f V r} \times 100
$$

has to be greater than the detection limit of the mass spectrometer (D), if a leak is to be detected. This implies that to detect a tracer gas, the fraction of gas leaked ( $f$ ) must satisfy the equation:

$$
f>\frac{y D}{\operatorname{Vr}(100 M-D)}
$$

Pertinent rod and capsule characteristics are given in Table A-1, and based on Table A-1, the fraction of tracer gas (M) can be calculated as shown in Table A-2.

For a detection limit of $1 \times 10^{-2} \%, D=0.01$. Since the capsules are filled to $1 \mathrm{~atm}$, the internal net capsule volume is equal to the capsule gas volume (y). The data in Tables A-1 and A-2 can be used to calculate the minimum detectable leak for each tracer gas using Equation $(A-1)$. This is shown in Table A-3. 
TABLE A-1

ROD AND CAPSULE CHARACTERISTICS

\begin{tabular}{|c|c|c|}
\hline Characteristics & H. B. Robinson & Peach Bottom \\
\hline Rod Volume (cc) & $25+7^{(A 1-A 3)}$ & $73.7^{(\mathrm{A} 4)}$ \\
\hline$V r=$ Gas Volume $(c c)$ & $370 \pm 10^{(A 1-A 3)}$ & $127.0^{(A 5)}$ \\
\hline Xenon Volume $(c c)$ & $3 . \overline{5} \pm 0.8^{(\mathrm{A} 3)}$ & $42.0^{(\mathrm{A} 5)}$ \\
\hline Krypton Volume (cc) & $0.37 \pm 0.03^{(\mathrm{A} 3)}$ & $5.53^{(A 5)}$ \\
\hline Internal Rod Pressue (psia) & $220 \pm 14(A 1-A 3)$ & $25.3^{(A 5)}$ \\
\hline Net Capsule Volume (r.s) & $6.32 *$ & $326.0^{*}$ \\
\hline Capsule Pressure (psia) & $15^{*}$ & $15.0^{\star}$ \\
\hline
\end{tabular}

TABLE A-2

FRACTION OF TRACER GAS (M)

\begin{tabular}{|c|c|c|}
\hline Gas & H. B. Robinson & Peach Bottom \\
\hline Kryplun & $1 \times 10^{-3}$ & $4.35 \times 10^{-2}$ \\
\hline Xeno & $9.5 \times 10^{-3}$ & 0.33 \\
\hline Helíum & ก.989 & 0.626 \\
\hline
\end{tabular}

TABLE A-3

DETECTION LIMITS $(f)$

\begin{tabular}{|c|c|c|c|}
\hline Reactor & Krypton & Xenon & Hel i um \\
\hline 4. $B$ & $0.19 \quad(19 \%)$ & $1.8 \times 10^{-2}(1.8 \%)$ & $1.7 \times 10^{-4}(0$ \\
\hline Peach Bottom & $0.006(0.6 \%)$ & $7.8 \times .10^{-4}(0.08 \%)$ & $4 \times 10^{-4}(0.04 \%)$ \\
\hline
\end{tabular}


If helium is used as a capsule fill gas, then krypton or xenon should be used as the tracer gas, and detection sensitivity would be decreased. An argon inert atmosphere was chosen so that helium could be detected, thus decreasing the size of the smallest leak that can be detected.

In order, though, to leak check the Swagelok ${ }^{\circledR}$ seals on the capsules, it is necessary to put some helium in the argon fill gas. Once again, if the amount of gas in the capsules is $y$ and the fraction of tracer gas in the capsule is $x$, then the volume of tracer is $y x$. After a leak from the rod occurs, the amount of tracer in the capsule will be $y x+V r M f$. Let the mass spectrometer detect a fractional change of $z$ (i.e., $10 \%$ increase means $z=1.1$ ). The final fraction of tracer in the capsule will be:

$$
\frac{y x+V r M f}{y+V r f}
$$

This must be greater than $z x$ or:

$$
\frac{y x+V r M f}{y+V r f}>z x
$$

therefore,

$$
f>\frac{y x(z-1)}{\operatorname{Vr}(M-z x)}
$$

One percent helium in the argon is sufficient for Swagelok ${ }^{\circledR}$ leak checking so $x=10^{-2}$. Using the values in Table $A-1$, the leak sensitivities in Table $A-4$ are generated from Equation (A-2). These limits are approximately an order of magnitude higher than those given in Table A-3 where no helium tracer was in the argon gas. This would indicate that xenon should be the primary rod leak detection gas for the Peach Bottom rods, and helium will continue to be the primary leak detection gas in the H. B. Robinson fuel.

${ }^{\circledR}$ Swagelok is a registered trademark of Crawford Fitting Co., Solon, $\mathrm{OH}$. 
LEAK DETECTION LIMITS ( $f$ ) FOR HELIUM GAS WITH

$1 \%$ HELIUM IN ARGON COVER GAS

Reactor

H. B. Robinson

Peach Bottom $\frac{f(\%)}{z=3} \quad \underline{z=1.1}$

$3.6 \quad 0.18$

$8.6 \quad 0.4$

\section{KEFEKENCES}

A1. A. A. Bauer, L. M. Lowry and J. S. Merrin, Progress un Evdlualinig Strength and Ductility of Irradiated Zircaloy During July Through September, BMI-1938, Battelle Memorial Institute, Columbus, $\mathrm{OH}, 1975$.

A2. A. A. Bauer, L. M. Lowry and J. S. Perrin, Evaluating Strength and Ductility of Irradiated Zircaloy, BMI-NUREG-1976, Battelle Memorial Institute, Columbus, OH, July. 1977.

A3. S. J. Daybjartsson, B. A. Murdock, D. E. Owens and P. E. MacDonald, Axial Gas Flow in Irradiated PWR Fuel Rods, TREE-NUREG-1158, EG\&G-Idaho, Idaho Falls, ID, September 1977.

A4. R. A. Lorenz, J. L. Cullins, M. F. Osborne, R. L. Towns and A. P. Malinauskas, Fission Product Release frull BWR Fuel Under LOCA Conditions, NUREG/CR-1773, Nuclear Regulatory Commission, Washington, DC, July 1981.

A5. V. W. Storhok, "Dresden-1 Fuel Rod Cover Gas Analysis," EG\&G-Idaho, Idaho Falls, ID, November 1979. 
A P P N D I X B

CLADDING OXIDATION

B-1 


\section{THIS PAGE}

\section{WAS INTENTIONALLY \\ LEFT BLANK}

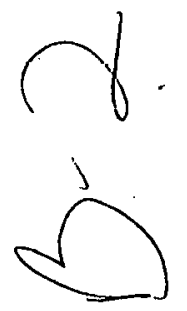


Oxidation rates of Zircaloy in a dry air atmosphere must be used to set the air pressure in the test capsule and to determine the effect of oxidation on the ultimate fuel rod lifetime. There have been many oxidation studies in water and steam, mostly at temperatures in excess of $500^{\circ} \mathrm{C}$, but relatively few studies in a dry atmosphere. The dry oxidation studies are also at temperatures above $500^{\circ} \mathrm{C}$ and were conducted for a short time (700 days was longest). (B1) Thus, the extent to which cladding will oxidize during testing or actual dry storage below $250^{\circ} \mathrm{C}$ is based on extrapolation of data.

Studies by Hillner in steam $(B 2)$ indicate that Zircaloy oxidation is a two step process. The first step, pre-transition, follows a " $t$ "1/3" dependence while the second step, post-transition, follows a " $t$ " dependence. This same two step behavior and time dependence was observed by Watson ${ }^{(B 1)}$ for oxidation of Zircaloy-2 in air between 500 and $700^{\circ} \mathrm{C}$. In fact, both studies indicated approximately the same time of transition as a function of temperature. This transition time can be expressed as:

$$
t_{t}=6.73 \times 10^{-7} \exp \left[11,975 / T\left({ }^{\circ} \mathrm{K}\right)\right] \text { days }
$$

At reactor operating conditions (approximately $350^{\circ} \mathrm{C}$ cladding temperature) transition occurs in approximately 150 days. Thus, when the rods enter dry storage or in this case testing, the exterior surface should have an oxide layer which is already growing as a post-transition oxide. It is not known whether the oxide will continue to grow as post-transition oxide or revert to pre-transition oxide growth rates at the lower storage temperatures. Since the oxide growth rate is faster in post-transition, that rate will be used to determine lifetimes and to set atmospheres.

Boase and Vandergraaf ${ }^{(B 3)}$ compared post-transition oxidation rate data above $500^{\circ} \mathrm{C}$ and found close agreement between oxidation in steam, water and air. The data fit a straight-line Arrhenius plot given by the equation:

$$
\text { Rate }\left(g / d m^{2} h\right)=9.46 \times 10^{5} \exp \left[-15810 / T\left({ }^{\circ} \mathrm{K}\right)\right]
$$


Equation ( $B-2)$ was used to extrapolate to the dry storage and testing temperature range, assuming that there is no mechanism change at the lower temperature.

\section{Oxidizing Atmosphere}

At $230^{\circ} \mathrm{C}$, the type 304 capsule material will have an immeasurably small oxidation rate; therefore, only Zircaloy oxidation need be considered to determine the oxygen supply in the capsule. The weight gain of the rod will be AtF, where $A$ is the surface area, $t$ is the test time and $F$ is the oxidation rate given by Equation (B-2). Thus the amount of oxygen consumed (N) is given by:

$$
N(\text { IIUTeS })=A t F / 32
$$

The partial fill pressure of oxygen at room temperature $(P)$ necessary to feed the oxidation process can then be calculated from the ideal gas law PV $=N_{R T}$, where $V$ is the net capsule volume and $T_{R T}$ is the temperature when the capsule is filled. Note that the air is $\sim 20 \%$ oxygen, the $\mathrm{fill}$ pressure of air required to supply the necessary oxygen is 5P. During the experiment, in order not to deplete the oxygen level in the air completely but only to drop it to 15\%; the air pressure has to be further increased by a factor of 4 or:

$$
P_{\text {air }}(\mathrm{atm})=20 \times \frac{A t F}{32} \times \frac{R_{\text {RT }}}{V}
$$

Combining Equations (B-2) and (B-4), the necessary fill pressure of air is:

$$
P_{\text {air }}(\text { psia })=5,35 \times 10^{7} \frac{\mathrm{A}\left(\mathrm{dm}^{2}\right) t(\mathrm{hr})}{V(1 \mathrm{iter})} \exp \left[\frac{-15810}{T\left({ }^{\circ} \mathrm{K}\right)}\right]
$$

The necessary physical parameters of the system are given in Table B-l.

Since every rod will not be de-encapsulated at each interim evaluation, there must be enough oxygen to last for at least a 2 -yr period or $t=1.752 \times 10^{4} \mathrm{hr}$. The necessary air pressure in the capsules as a function of test temperature is given in Table B-2. 
TABLE B-T

FUEL ROD AND CAPSULE CHARACTERISTICS

$\begin{array}{lcc}\frac{\text { Characteristics }}{\text { Rod Surface Area }\left(\mathrm{dm}^{2}\right)} & \frac{\text { B. Robinson }}{13.07^{(\mathrm{B} 4)}} & \frac{\text { Peach Bottom }}{18.38^{(\mathrm{B} 5)}} \\ \text { Capsule Volume (1iter) } & 0.632 & 0.326\end{array}$

TABLE B-2

CAPSULE AIR PRESSURE (psia)

\begin{tabular}{|c|c|c|}
\hline $\begin{array}{l}\text { Temperature } \\
\left({ }^{\circ} \mathrm{C}\right)\end{array}$ & H. B. Robinson & Peach Bottom \\
\hline 200 & 0.24 & 0.64 \\
\hline 210 & 0.48 & 1.28 \\
\hline 220 & 0.92 & 2.48 \\
\hline 230 & 1.72 & 4.72 \\
\hline 240 & 3.20 & 8.72 \\
\hline 250 & 5.76 & 15.70 \\
\hline
\end{tabular}

Based on the above calculations, one atmosphere of air should be sufficient to supply the necessary nxygen in the closed capsules. Of course, in the open filtered capsules, there is a continuous supply of air.

\section{Oxidation During Testing}

The Zircaloy cladding will oxidize to $\mathrm{ZrO}_{2}$. Therefore, for every mole of $\mathrm{O}_{2}$ weight gain, there is a mole of $\mathrm{Zr}$ oxidized. If the weight gain per unit area of Zircaloy is divided by the density of Zircaloy $(\rho)$, then the thickness of the oxygen layer can be calculated. This thickness can be expressed using Equation (C-2) as:

$$
h(\mathrm{mil})=1.66 \times 10^{6} \exp \left[-15810 / \mathrm{T}\left({ }^{\circ} \mathrm{K}\right)\right] t(\mathrm{hr})
$$


For a 50-month test, the total oxide layer expected is $1.34 \times 10^{-3} \mathrm{mil}$ at $230^{\circ} \mathrm{C}$ and $4.45 \times 10^{-3}$ at $250^{\circ} \mathrm{C}$. Even for the higher temperature, the thinner-walled H. B. Robinson cladding will have only $0.02 \%$ of the wall oxidized. This should be an indiscernible amount and not affect the cladding stresses. It is interesting to note that for a 50-year storage period, the expected cladding oxidation should only be $0.24 \%$ of the cladding wall and once again not affect the cladding stress.

\section{REFERENCES}

B1. R. D. Watson, On the Oxidation of Zirconium Alloys in Air and the Dimensional Changes Associated with Oxidation, AECL-3375, Atomic Energy of Canada, Ltd, Chalk River, Ontario, Canada, June 1969.

B2. E. Hillner, Corrosion and Hydriding Performance Evaluation of Three Zircaloy-2 Cladding Fuel Assemblies After Continuous Exposure in PWR Cores 1. and 2 at Shippingport, PA, WAPD-TM-1412, Westinghouse Electric Corporation, Atomic Power Division, Pittsburgh, PA, January 1980.

B3. D. G. Boase and T. T. Vandergraaf, "The Canadian Spent Fuel Storage Canister: Some Materials. Aspects," Nuc1. Technol. 32, p. 60, January 1977.

B4. S. J. Daybjartsson, B. A. Murdock, D. E. Owens and P. E. MacDonald, Axial Gas Flow in Irradiation PWR Fuel Rods, TREE-NUREG-1158, EG\&G-Idaho, Idaho Fal1s, ID, September 1977.

B5. N. H. Larson, Core Design and Operating Data for Cycles 1 and 2 of Peach Bottom-II, EPRI Report NP-563, Electrical Power Research Institute, Palo Alto, CA, July 1978. 
A P P ENDI $X$ C

FUEL OXIDATION

$c-1$ 


\section{THIS PAGE \\ WAS INTENTIONALLY LEFT BLANK}

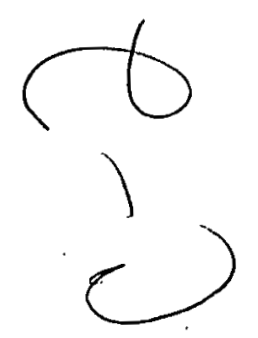




\section{FUEL OXIDATION}

Two questions were addressed concerning fuel oxidation:

- In an unlimited air situation, how far will the oxidation front extend?

- In a closed capsule, if a breach occurs, how much fuel will oxidize before the $\mathrm{O}_{2}$ is depleted?

Boase and Vandergraaf $(\mathrm{Cl})$ give an activation energy for the progression of the oxidation front below $275^{\circ} \mathrm{C}$. The data is of such a quality that a second extrapolation could be made using all of the Canadian data, which gives a higher oxidation rate. For the moment, it is assumed that the higher temperature data $\left(\mathrm{T}>250^{\circ} \mathrm{C}\right)$ can be extrapolated below $250^{\circ} \mathrm{C}$. The two oxidation rates are:

$$
\begin{array}{ll}
V_{C}(\mathrm{~cm} / \mathrm{min})=1.23 \times 10^{13} \exp \left[-20933 / \mathrm{T}\left({ }^{\circ} \mathrm{K}\right)\right] & T<275^{\circ} \mathrm{C} \\
V_{H}(\mathrm{~cm} / \mathrm{min})=338 \exp \left[-7612 / \mathrm{T}\left({ }^{\circ} \mathrm{K}\right)\right] & \text { a) } 1 \mathrm{~T}
\end{array}
$$

It is not clear from Boase and Vandergraaf, $(\mathrm{Cl})$ whether the oxidation front is defined in one direction from the breach or the total length of the oxidized material. For conservatism, assume that the data is the front movement in only one direction, and hence velocities in Equations (C-1) and ( $C-2)$ must be doubled. Therefore, the length of fuel oxidized $(L)$ in a time $(t)$ will begin from Equations $(\mathrm{C}-1)$ and $(\mathrm{C}-2)$ by:

$$
\begin{aligned}
& \mathrm{L}_{C}(\text { in })=5.81 \times 10^{14} \mathrm{t}(\mathrm{hr}) \exp \left[-20933 / \mathrm{t}\left({ }^{\circ} \mathrm{K}\right)\right] \\
& \mathrm{L}_{H}(\text { in })=1.6 \times 10^{4} \mathrm{t}(\mathrm{hr}) \exp \left[-7612 / \mathrm{T}\left({ }^{\circ} \mathrm{K}\right)\right]
\end{aligned}
$$

Making the assumption that the defected rods will be examined at least once a year, i.e., $t=8.74 \times 10^{3} \mathrm{hr}$, the expected length of the oxidation front or cladding opening is given in Figure $\mathrm{Cl}$. 


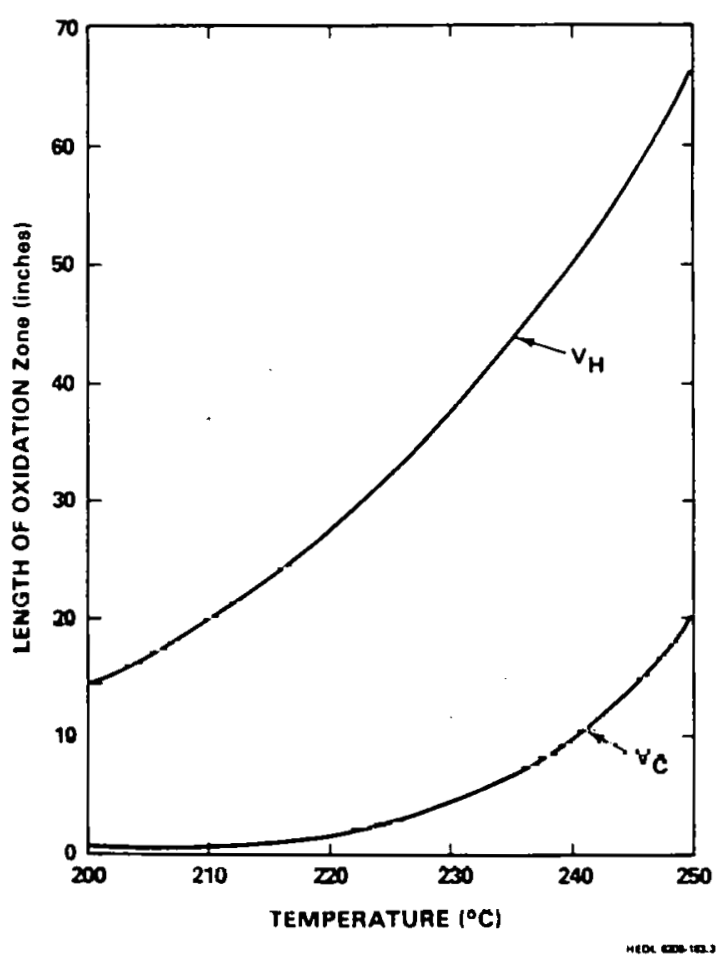

FIGURE C1. Oxidation Front Length for 1-year Period at Temperature Based on Two Different Oxidation Rate Predictions.

Based on Boase and Vandergraaf data, (C1) if in fact below $250^{\circ} \mathrm{C}$ the $\mathrm{UO}_{2}$ converts to $\mathrm{U}_{3} \mathrm{O}_{8}$, there should be splitting of the cladding. At $230^{\circ} \mathrm{C}$ for a year, the two extrapolations of the oxidation rates predict a $37-i n$. difference in the length of the split. If no splitting is seen, then one of two possibilities exists:

1. Ihe oxidation rate of $\mathrm{UO}_{2}$ is not inear but drops off procipitously below $250^{\circ} \mathrm{C}$. A curve through the Boase arid Vandergraaf data might indicate this.

2. Oxidation of $\mathrm{UO}_{2}$ bclow $250^{\circ} \mathrm{C}$ results in $\mathrm{U}_{3} \mathrm{O}_{7}$ noL $\mathrm{U}_{3} \mathrm{O}_{8}$ and no stréss is placed on the r.tadding.

Should no cladding cracking occur, which is the writer's projection, delineation between these two cases can only be determined by post-test metallography and $x$-ray examination of the rod. 
During a period of duration $t$, the length of fuel oxidized will be Vt. If $A$ is the area of the pellet, the volume of fuel oxidized is VAt. The weight (W) of the $\mathrm{UO}_{2}$ oxidized can be written as:

$$
W=\text { VAt } \rho f
$$

where $\rho$ is the theoretical density of $U_{2}$ and $f$ is the fraction of theoretical density of the pellet. The number of moles of $\mathrm{UO}_{2}$. that are oxidized $\left(\mathrm{N}_{U 0_{2}}\right)$ is given by $\mathrm{N}_{\mathrm{UO}_{2}}=\mathrm{W} / 267$.

As discussed in the main text, there is some uncertainty as to whether $\mathrm{UO}_{2}$ oxidizes to $\mathrm{U}_{3} \mathrm{O}_{7}$ or $\mathrm{U}_{3} \mathrm{O}_{8}$ in the temperature regime of interest although most data says $\mathrm{U}_{3} \mathrm{O}_{7}$ is the correct oxidation product. The two reactions are:

$$
\begin{aligned}
& 6 \mathrm{UO}_{2}+\mathrm{O}_{2} \rightarrow 2 \mathrm{U}_{3} \mathrm{O}_{7} \\
& 3 \mathrm{UO}_{2}+\mathrm{O}_{2} \rightarrow \mathrm{U}_{3} \mathrm{O}_{8}
\end{aligned}
$$

If the reaction product is $\mathrm{U}_{3} \mathrm{O}_{7}$; then the moles of $\mathrm{O}_{2}$ consumed $\left(\mathrm{N}_{2}\right)$ is $\mathrm{N}_{\mathrm{UO}_{2}} / 6$. On the other hand, if it is $\mathrm{U}_{3} \mathrm{O}_{8}$, the moles of $\mathrm{UO}_{2}$ consumed is $\mathrm{N}_{\mathrm{Un}_{2}} / 3$. Therefore, the weight of the $\mathrm{UO}_{2}$ oxidized. $(W)$ is given by:

$$
W=267 \mathrm{~N}_{0}\left(\begin{array}{l}
3 \\
6
\end{array}\right)
$$

where $\left(\begin{array}{l}3 \\ 6\end{array}\right)$ is a multiplication factor depending on the oxidation reaction.

Since the front propagates in two directions, the length of the $\mathrm{U}_{2}$, oxidized is $2 V t=L$. Combining Equations $(C-4)$ and $(C-6)$, the length of the $\mathrm{UO}_{2}$ oxidized is:

$$
L=\frac{534}{A \rho f} N_{0_{2}}\left(\begin{array}{l}
3 \\
6
\end{array}\right)
$$


The oxygen partial pressure in a capsule is $P_{0_{2}}=P_{a i r} / 5$, where $P_{a i r}$ is the air pressure in the capsule. Using the ideal gas law, the number of moles of oxygen in the capsule are given by:

$$
\mathrm{N}_{0_{2}}(\text { mole })=P_{\text {air }}(\text { psia }) V_{\text {cap }}(1 \text { iter }) \times 5.53 \times 10^{-4}
$$

Equation ( $\mathrm{C}-8)$ is based on the assumption that the cladding is not depleting the $0_{2}$ supply. This is not strictly correct, but the assumption does allow the result to be made independent of when in the storage cycle the breach occurs. Combining Equations $(C-7)$ and $(C-8)$, the oxidized fuel length is:

$$
L=\frac{0.3 P_{\text {air }}\left(\text { psia) } \bar{V}_{\text {cap }}(1 \text { iter })\right.}{A \mu l}\left(\begin{array}{c}
3 \\
\bar{b}
\end{array}\right)
$$

Using the input from Table $\mathrm{C}-1$, the oxidized length for the H. B. Robinson fuel ranges from 0.5 to $1.0 \mathrm{in.}$, and the oxidized fuel length in the Peach Bottom fuel ranges from 0.14 to $0.3 \mathrm{in}$. Substituting $L=2 \mathrm{Vt}$ into Equation (C-9), it is determined that if breach occurs within the first 7 months of testing at $210^{\circ} \mathrm{C}$ or above, the reaction should have gone to completion and the uxygen depleted.

\section{TABLL $C-1$}

FUEL ANU STORAGE CHARACTERISTICS TO

CALCULATE FUEL OXIDATION LENGTH

\begin{tabular}{ccc} 
Chapdidertstics & H. B. Robinson & Peach Bottom \\
\cline { 2 - 3 }$V_{\text {cap }}$ (1iter) & 0.632 & 0.326 \\
$f$ & 0.92 & 0.94 \\
$A_{\text {pel }}\left(\mathrm{cm}^{2}\right)$ & 0.682 & 1.15 \\
$\rho$ & 10.98 & 10.98 \\
$P_{\text {dir }}$ (psia) & 14.7 & 14.7
\end{tabular}


Due to the uncertainties in the oxidation rates of $\mathrm{UO}_{2}$ and the final oxidation state of uranium, the oxidation front could extend anywhere from 0 to 37 in. at $230^{\circ} \mathrm{C}$. It is our feeling that the fuel oxidation state will be $\mathrm{U}_{3} \mathrm{O}_{7}$ and while there may possibly be a large oxidation front, no cladding splitting due to the oxidation is expected. In the closed capsule, the oxidation front should extend no more than 1 inch. Whether all the oxygen is depleted depends on the time in the run when breach occurs. If breach occurs at the start of the run, there is ample time for complete oxygen depletion.

\section{REFERENCES}

C1. D. G. Boase and T. T. Vandergraaf, "The Canadian Spent Fuel Storage Canister: Some Materials Aspects," Nucl. Technol. 32, p. 60, January 1977. 
A P P E N D I $X \quad D$

WE IGHING AS A MEANS TO STUDY

FUEL OXIDATION IN WHOLE ROD TESTS

D -1 


\section{THIS PAGE}

\section{WAS INTENTIONALLY \\ LEFT BLANK}

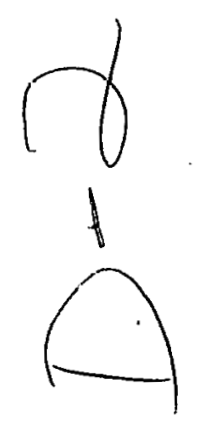


WEIGHING AS A MEANS TO STUDY

FUEL OXIDATION IN WHOLE ROD TESTS

Weight change was also suggested as a possibility for determining oxidation behavjor but was rejected due to it's insensitivity. Two cases can occur: (1) the cladding breach does not extend, or (2) the breach does extend. Breach extension can be established visually. If the breach does not extend, there are two subevents which might have occurred: (1) $\mathrm{U}_{3} \mathrm{O}_{7}$ formed, or (2) $\mathrm{U}_{3} \mathrm{O}_{8}$ formed, but did not impose enough stress to crack the cladding. These three possibilities were considered in some detail.

The parameters for the case where no splitting occurs and $\mathrm{U}_{3} \mathrm{O}_{7}$ is formed are given in Table D1. Disregarding weight losses due to crud spallation, there should be a weight gain due to $\mathrm{UO}_{2}$ oxidation to $\mathrm{U}_{3} \mathrm{O}_{7}$. If cell balances for rods have an accuracy of $0.05 \mathrm{lb}$, (D1) then the minimal detectable weight change is $0.1 \mathrm{lb}$. The complete H. B. Robinson rod would have to oxidize, and $38 \mathrm{in.}$ of the Peach Bottom rod would have to oxidize to be detectable. From the Boase and Vandergraaf data $(D 4)$ only between 2 and 37 inches of oxidation are expected. Therefore, weight change is not a practical method if no cladding splitting is observed and $\mathrm{U}_{3} \mathrm{O}_{7}$ is formed.

If no cladding splitting is observed and $\mathrm{U}_{3} \mathrm{O}_{8}$ forms, then there is an additional consideration. Since $\mathrm{U}_{3} \mathrm{O}_{8}$ has a different lattice structure than the $\mathrm{UO}_{2}$ fission, gas bubbles on the grain boundaries, representing the majority of the gas remaining in the pellet, will be liberated. This will lead to a net decrease in the rod weight. The weight loss calculations due to fission gas release are given in Table D2a. If the calculations that lead to Table DI were repeated for the $\mathrm{UO}_{2} \rightarrow \mathrm{U}_{3} \mathrm{O}_{8}$ reaction, Table $\mathrm{D} 2 \mathrm{~b}$ would be generated. It is observed that the weight loss due to fission gas release is only a small perturbation on the weight gain from fuel oxidation to $\mathrm{U}_{3} \mathrm{O}_{8}$. For the $\mathrm{H}$. B. Robinsor rod, half of the rod would have to be oxidized for a weight change to be measurable. Detectable weiglit changes should be measurable for the Peach Bottom case if the rate is at the upper end of the expected range, but the measurement is uninterpretable. 
TABLE D-1

WEIGHT CHANGE MEASUREMENTS FOR $\mathrm{U}_{3} \mathrm{O}_{7}$ FORMATION

(No Cladding Splitting)

Measurements

$\mathrm{UO}_{2} / \operatorname{Rod}(\mathrm{lb})$

$\mathrm{UO}_{2}$ (mole)

$\mathrm{O}_{2}$ Consumed for Complete Rod Oxidation (mole)

$\mathrm{O}_{2}$ Consumed ( $\mathrm{Ib}$ )

Minimal Detectable 0xidation Length (in.)

Expected 0xidation Longth* Based on Ref D4 (in.) $\frac{\text { H. B. Robinson }}{5.37^{(D 2)}} \quad \frac{\text { Peach Bottom }}{9.53^{(D 3)}}$

9.06

16.1

1.51

2.68

0.11

0.38

130.0

38.0

2 to 37

2 tó 37

*Based on 20-month operation.

The question would remain: "Is the weight change due to 19 in. of $U_{3,} O_{y}$ formation, 38 in. of $\mathrm{U}_{3} \mathrm{O}_{7}$ formation, or a combination of reactions?" There is no way of telling except by a structure disruption noticed in the $\gamma$-scan. But if $\gamma$-scanning is used, why measure weight change in the first place? Once again, the method is not recommended.

The third possibility is cladding splitting due to $\mathrm{U}_{3} \mathrm{O}_{8}$ formation. In this case, there is going to be weight gain from the $\mathrm{U}_{3} \mathrm{O}_{8}$ that forms and remains in the rod, and a weight loss from the $U_{3} 0_{8}$ that falls out of the rod. $U_{3} 0_{8}$ has a density of $8.3 \mathrm{~g} / \mathrm{ss}$. The minimum lerlylh of fuel that would have to fall out for weight detection is $1.4 \mathrm{in}$. for $\mathrm{H}$. B. Robinson and $0.75 \mathrm{in}$. for Peach Bottom. This size crack opening is very easy to observe. Since in all likeli-. hood the fallout will be incomplete (1.e., pieces will adhere and remain inside the cladding), there is no way to correct the weight measurement to determine how far into the uncracked cladding that the $\mathrm{U}_{3} \mathrm{O}_{8}$ front penetrates. Once again, weight measurements are not satisfactory. 
TABLE D-2

WEIGHT CHANGE. MEASUREMENTS FOR DETERMINING $U_{3} 0_{8}$ FORMATION

a) Fission Gas Release Weight Loss $-\mathrm{UO}_{2} \rightarrow \mathrm{U}_{3} \mathrm{O}_{8}$ Reactor,

H.B. Robinson

$386.0^{(D 2)}$

$0.1^{(\mathrm{D} 2)}$

$0.9^{(D 2)}$

$0.2^{(D 5)}$

195.0

1735.0

0.009

0.077

0.002

0.022

0.024
Rod Gas Volume (cc a stp)

$\% \mathrm{Kr}$ in Gas

$\% \mathrm{Xe}$ in Gas

$\%$ Fission Gas Release

Volume $\mathrm{Kr}$ Produced

Volume Xe Produced

Moles $\mathrm{Kr}$ 'Produced

Moles Xe Produced

1 bs $\mathrm{Kr}$ Produced

Ibs Xe Produced

Total Weight of Gas (1b)
Peach Bottom

120.0

4.5

34.5

3.0

180.0

1380.0

0.008

0.062

0.001

0.018

0.019

b) Oxidation Weight Gain $-\mathrm{UO}_{2} \rightarrow \mathrm{U}_{3} \mathrm{O}_{8}$

3.02

0.21

69.0

2-37
$\mathrm{O}_{2}$ Consumed for Complete Rod oxidation (mole)

$\mathrm{O}_{2}$ Consumed ( $\mathrm{lb}$ )

Mini illd 1 Detectable Length (in)

Expected Oxidation Length*

on Boase and Vandergraaf(D4)
5.37

0.76

19.0

$2-37$

*Based on 20-months operation. 


\section{REFERENCES}

D1. R. B. Davis, Pretest Nondestructive Examination Data Summary Report on Turkey Point Spent Fuel Assemblies D01, D04 and D06 for the Climax-Spent Fuel Test, HEDL-TME 80-83, Hanford Engineering Development Laboratory, Richland, WA, January 1981.

D2. S. J. Daybjartsson, B. A. Murdock, D. E. Owens and P. E. MacDonald, Axial Gas Flow in Irradiated PWR Fuel Rods, TREE-NUREG-1158, EG\&GIdaho, Idaho Falls, ID, September 1977.

D3. N. H. Larson, Core Design and Operating Data for Cycles 1 and 2 of Peach Bottom-II, EPRI Report NP-563, Electrical Power Research Institute, Palo ATto, CA, June 1978.

D4. D. G. Boase and T. T. Vandergraaf, "The Canadian Spent Fuel Storage Canister: Some Matertals Aspects," Nucl. Technol. 3?, p. 60. January 1977 .

D5. R. A. Lorenz, J. L. Collins, A: P. Malinauskas, 0. L. Kirkland and R. L. Towns, Fission Product Release for Highly Irradiated LWR Fuel, NUREG/CR-0722, ORNL/NUREG/TM-287, Oak Ridge National Laboratory, Oak Ridge, TN, February 1980. 


\section{U.S. NUCLEAR REGULATORY COMMISSION \\ BIBLIOGRAPHIC DATA SHEET}

TITLE ANO SUBTITLE (Add Volume No., if aporoporiare)

A TECHNICAL TEST DESCRIPTION OF THE NRC LONG-TERM

WHOLE ROD AND CRUD PERFORMANCE TEST

AUTHOR(S)

Robert E. Einziger, Robert L. Fish

PERFORMING ORGANIZATION NAME AND MAILING ADDRESS (Include Zip Code)

Westinghouse Hanford Company

P. 0. Box 1970

Richland, Washington 99352

12. SPONSORING ORGANIZATION NAME AND MAILING ADDRESS (Include Zip Code)

Office of Nuclear Regulatory Research

U. S. Nuclear Regulatory Commission

Division of Engineering Technology Washington, D. C. 20555

13. TYPE OF REPORT

Technical

PERIOD COVERED (Inclusive dates)

March $1982 \rightarrow$ September 1982

\section{SUPPLEMENTARY NOTES}

14. (Leave blank)

16. ABSTRACT (200 words or less)

Westinghouse Hanford Company (WHC) and EG\&G-Idaho are jointly conducting a long-term low-temperature spent fuel whole rod and crud behavior test to provide the Nuclear Regulatory Commission (NRC) with information to assist in the licensing of light water reactor (LWR) spent fuel dry storage facilities.

Readily available fuel rods from an $\mathrm{H}$. B. Robinson (PWR) fuel assembly and a Peach Bottom 2 (BWR) fuel assembly were selected for use in the 50 month test. Both intact and defected rods will be tested in inert and oxidizing atmospheres. A $230^{\circ} \mathrm{C}$ test temperature was selected for the first 10 month run. Both nondestructive and destructive exams are planned to characterize the fuel rod behavior during the five year test. Four interim exams and a tinal exam will be conducted. Crud spallation behavior will be investigated by sampling the crud particulate from the test capsule at each of the four interim exams and at the end of the test.

The background to whole rod testing, description of rod breach mechanisms, along with a detailed description of the test, are presented in this document.

\section{KEY WORDS AND DOCUMENT ANALYSIS}

Spent $F \cdot$ ?

Dry Storage

Fuel Rod Performance

Peach Bottom-II

H. B. Robinson 2

Whole Rod Testing 17a. DESCRIPTORS

BWR Rods

PWR Rods

Fuel Oxidation

Zlrcaloy $\mathrm{Cladding}$

Defected Fuel

Crud

170. IDENTIFIERSIOPEN.ENDED TERMS

18. AVAILABILITY STATEMENT

UNLIMITED

\begin{tabular}{ll|l} 
19. SE CUĀITY CLASS (This report) & 21. NO. OF PAGES
\end{tabular} Unclassified

20. SE CURITY CLASS (This page) Unclassificd 
UNITED STATES

NUCLEAR REGULATORY COMMISSION

WASHINGTON, D.C. 20555

OFFICIAL BUSINESS

PENALTY FOR PRIVATE USE, $\$ 300$
FOURTH CLASS MAIL

POSTAGE \& FEES PAID

USNRC

WASH D

PERMIT NO G.67 